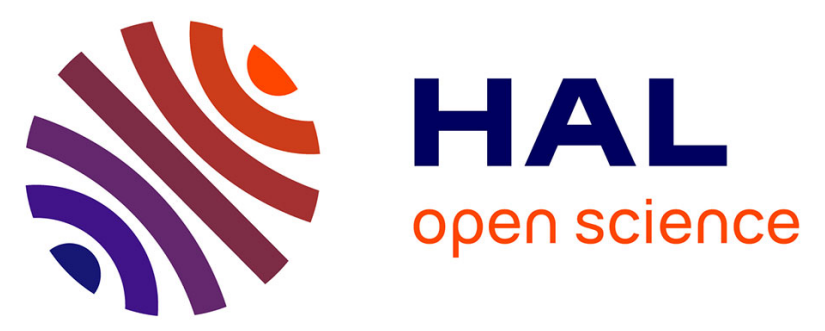

\title{
Dinoflagellate cyst population evolution throughout past interglacials: Key features along the Iberian margin and insights from the new IODP Site U1385 (Exp 339)
}

Frédérique Eynaud, Laurent Londeix, Aurélie Pénaud, Maria-Fernanda Sanchez-Goni, Dulce Oliveira, Stéphanie Desprat, Jean-Louis Turon

\section{To cite this version:}

Frédérique Eynaud, Laurent Londeix, Aurélie Pénaud, Maria-Fernanda Sanchez-Goni, Dulce Oliveira, et al.. Dinoflagellate cyst population evolution throughout past interglacials: Key features along the Iberian margin and insights from the new IODP Site U1385 (Exp 339). Global and Planetary Change, 2015, in press. 10.1016/j.gloplacha.2015.12.004 . insu-01244297

\section{HAL Id: insu-01244297 https://hal-insu.archives-ouvertes.fr/insu-01244297}

Submitted on 15 Dec 2015

HAL is a multi-disciplinary open access archive for the deposit and dissemination of scientific research documents, whether they are published or not. The documents may come from teaching and research institutions in France or abroad, or from public or private research centers.
L'archive ouverte pluridisciplinaire HAL, est destinée au dépôt et à la diffusion de documents scientifiques de niveau recherche, publiés ou non, émanant des établissements d'enseignement et de recherche français ou étrangers, des laboratoires publics ou privés. 
Dinoflagellate cyst population evolution throughout past interglacials: key features along the lberian margin and insights from the new IODP Site U1385 (Exp 339)

Frédérique Eynaud (1), Laurent Londeix (1), Aurélie Penaud (2), Maria-Fernanda SanchezGoni (1, 3), Dulce Oliveira $(1,3,4,5)$, Stéphanie Desprat (1, 3), \& Jean-Louis Turon (1)

(1) Université de Bordeaux, UMR CNRS 5805 EPOC (Environnements et Paleoenvironnements Oceaniques et Continentaux), Allée Geoffroy St Hilaire, 33615 Pessac Cedex, France

(2) UMR 6538 CNRS Laboratoire Domaines Océaniques, Université de Brest (UBO)- Institut Universitaire Européen de la Mer (IUEM), Place Nicolas Copernic, Plouzané, France

(3) EPHE, UMR CNRS 5805 EPOC (Environnements et Paleoenvironnements Oceaniques et Continentaux), 33615 Pessac Cedex, France

(4) Divisão de Geologia e Georecursos Marinhos, Instituto Português do Mar e da Atmosfera (IPMA), Av. de Brasília 6,1449-006 Lisbon, Portugal

(5) CIMAR, Associated Laboratory, Porto, Portugal

*Corresponding author; e-mail: f.eynaud@epoc-u-bordeaux1.fr; Phone: +33-(0)54000-3319 
ABSTRACT

IODP 339 Site U1385 ("Shackleton site", e.g. Hodell et al., 2013a), from the SW Iberian margin, offers the opportunity to study marine microfossil population dynamics by comparing several past interglacials and to test natural shifts of species that occurred across these warm periods, in a subtropical context. Here, more specifically, we present results obtained for the dinoflagellate cyst (dinocyst) population integrated at a regional scale thanks to the addition of data from proximal sites from southern Iberian margin. When possible, observations made using the dinocyst bio-indicator are compared to additional proxies from the same records in order to test the synchronicity of the marine biota response. Pollen data available for some of the compiled marine sequences also offer the opportunity to directly compare marine biota with terrestrial ecosystem responses. This spatio-temporal compilation reveals that, over the last $800 \mathrm{ka}$, surface waters around Iberia were tightly coupled to (rapid) climate changes and were characterised by coherent dinocyst assemblage patterns, highlighting a permanent connection between Atlantic and Mediterranean waters as evidenced through a continuous exchange of dinocyst populations. Some index species well illustrate the evolution of the regional hydrographic context along time, as for instance Spiniferites and Impagidinium species, together with Lingulodinium machaerophorum, Bitectatodinium tepikiense and heterotrophic brown cysts. They constitute key bio-indicators in context of natural environmental shifts at long and short timescales.

KEYWORDS: dinocysts, interglacials, biodiversity and climate shifts, southern Iberian margin 


\section{Introduction}

Drastic marine biodiversity changes that occurred over the last century raise key questions today in connection with the concept of ecosystem resilience to environmental changes (e.g. Millenium Ecosystem Assessment synthesis reports, 2005). This is especially true for neritic ecosystems that encountered major perturbations especially related to the geochemical balances of sea-surface waters (e.g. eutrophication, pollution contaminants, acidification e.g. Crutzen, 2002) but also to physical parameters (e.g. SST warming, sea-level changes, river nutrient loads). At present, natural environmental trends are hidden by anthropogenic forcings and reference points are lacking. The natural state is only found in the recent past, outside of the modern instrumental period (i.e. the last century), thus preventing actualistic studies from defining robust baselines for environmental predictions and trajectories. Paleostudies carried out on fossil sediment archives thus provide invaluable information (e.g. Wilis et al., 2010) even if they are integrating only a partial view of the paleobiodiversity, being only indirectly and incompletely representative of past biomes and biotopes. Interglacial optima, and especially their surrounding transitional periods (both deglaciations and glacial inceptions), represent key intervals where ecosystems, comparable to modern ones, could be tested along large amplitude ecological shifts (e.g Willis et al., 2010). They permit us to test if the marine biota offers the same recurrent kind of transient populations during such shifts and if so, to picture characteristic patterns that could be recognized within the assemblages. Are there typical species that could be considered as 
pioneers, opportunistic or pre-adapted, and so repetitive scenarios that could provide us with a predictive ecological model for the marine biota evolution?

For this study we based our approach on the dinoflagellate cyst (dinocyst) proxy, an organicwalled bio-indicator related to the phytoplankton realm which constitutes sexual reproduction remains of some dinoflagellate species (e.g. de Vernal and Marret, 2007; Ellegaard et al., 2013). Fossil dinocysts have long been used in Mesozoic-Cenozoic paleoceanographic studies to reconstruct past hydrographical patterns qualitatively as well as quantitatively through transfer functions (e.g. Wiliams, 1971; Turon, 1978; de Vernal et al., 2001; Houben et al., 2012; de Schepper et al., 2013; Mertens et al., 2014). They constitute a robust planktic group to document past sea-surface ecological changes (e.g. Marret and Zonneveld, 2003; Zonneveld et al., 2013) and are especially powerful in neritic environments where their motile thecal forms proliferate preferentially (e.g. Dale, 1983; Dodge and Harland, 1991).

Here we compare the evolution of dinocyst relative abundances across four of the most studied interglacials with regard to their climate dynamics: Marine Isotopic Stage (MIS) 1, 5, 11 and 19. We thus gathered sedimentary sequences (along which dinocyst assemblages have been analysed at high resolution) from the south-western European margin (Iberia), from its Atlantic side as well as from the inner Alboran Sea. This compilation, providing an integrated view of dinocyst assemblage evolution in space and time from a sensitive subtropical area (e.g. Giorgi, 2006), includes new original analyses on the IODP 339 Site U1385 (Hodell et al., 2013a and b). It gives us the opportunity to: i) document poorly known dinocyst populations from the interglacial MIS 19 and 11, and ii) study ecological interactions through several climate cycles of the Quaternary between two end-member environments 
on either sides of the Gibraltar strait: the Mediterranean Basin (residual Tethys) and the North Atlantic.

\section{Environmental setting: key features}

The modern hydrography of the southern Iberian margin is mainly forced by water mass exchanges with North-Atlantic waters penetrating the Alboran Sea at the surface, whereas deep saltier waters exit the Mediterranean at depth (Mediterranean Overflow Water or MOW). This scheme is mainly related to contrasted density budgets in between the two respective basins, however modulated by atmospheric forcing throughout the transfer of wind stress to surface currents, such as the Azores and Portugal currents for the Atlantic, or the western/ eastern anticyclonic gyres associated with the Algerian current for the Alboran (e.g. Rohling et al., 1995; Johnson, 1997; Font et al., 2000; Mauritzen et al., 2001; Arístegui et al., 2005, 2009, see Figure 1). This dynamical pattern evolves seasonally /yearly according to meridional shifts / contractions - extensions of the subtropical North Atlantic gyre, inducing changes in the temporality of upwelling cells and thus major modifications of the sea-surface productivity conditions (Arístegui et al., 2005; Peliz et al., 2005; Relvas et al., 2007). At millennial time scales, significant modulations of the MOW have been recorded during major climate transitions associated with boreal ice-sheet collapses (i.e. the wellknown Heinrich events, e.g. Heinrich, 1988) with a consensus supporting synchronous accelerations of MOW during these cold episodes (e.g. Cacho et al., 2000; Voelker et al., 2006; Rogerson et al., 2010). This also resulted in drastic consequences in water mass 
surface exchanges with the reorganisation of the Alboran gyres and obvious impacts on seasurface productivity on either sides of Gibraltar (Penaud et al., 2011).

\section{Methods}

This study relies on new unpublished data (IODP 339 Site U1385 MIS 19 and 11 sections - i.e. from the 788-749 ka and 410-384 ka age intervals respectively - from the "Shackleton site", e.g. Hodell et al., 2013a,) and also gathers several previously published and unpublished dinocyst records from the Southern Iberian margin (Figure1; see Table 1 for key elements concerning each studied core). We selected marine sequences that could provide us a fine enough analytical resolution regarding dinocyst assemblage patterns through time and where comparative data exists from other paleoenvironmental proxies (mainly derived from planktic foraminiferal and pollen assemblages, mono-specific foraminifera $\left.\delta^{18} \mathrm{O}\right)$.

Site U1385 was drilled from the SW Iberian Margin during IODP Expedition 339 (e.g. Hodell et al., 2013a) with the aim of extending further back in time the range of the exceptional piston cores previously retrieved in this area (including those listed in Table 1). Its stratigraphy was built upon a combination of chemo-stratigraphic proxies (Hodell et al., 2013a; this volume), i.e. Ca/Ti ratio, measured in all holes by XRF core scanning to construct a composite section, coupled to benthic foraminifera oxygen isotopes which were correlated to the marine $\delta^{18} \mathrm{O}$ LR04 stack (Lisiecki and Raymo, 2005). More details regarding this stratigraphical work can be found in Hodell et al. (2013a and b; this volume). Concerning the 
other published paleoceanographical records used in this study, we strictly used the age models as initially established and published by the authors (cf. Table 1).

Palynological preparations were conducted on IODP 339 Site U1385, Hole D, Core 10H between sections 3 and 6 which encompass MIS 19 and on Hole D, Core 7H section 1 and Hole $\mathrm{E}$, Core $6 \mathrm{H}$ sections 5 and 6 for MIS 11. The preparation techniques follow standard procedures and can be found at http://www.epoc.ubordeaux.fr/index.php?lang=fr\&page=eq_paleo_pollens. Acetolysis was not employed to avoid destruction of heterotrophic dinocyst taxa such as Polykrikaceae and Brigantedinium cysts (Marret, 1993; Combourieu-Nebout et al., 1998; Kodrans-Nsiah et al., 2008). The samples were used together for dinocyst and pollen analyses (Sànchez-Goñi et al., this volume) with two set of slides mounted independently to facilitate each kind of observations (i.e. glycerine jelly coloured with fushine for dinocysts and bidistilled glycerine for pollen). Dinocysts were counted on the fraction 10-150 $\mu \mathrm{m}$ (from 47 to 365 -average 187- specimens per sample) using a Zeiss PrimoStar light microscope at x400 magnifications. Identifications were based on Turon (1984), de Vernal et al. (1992) and Rochon et al. (1999). The nomenclature conforms to Fensome et al. (1998) and Fensome and Williams (2004), and dinocyst assemblages were described by the percentages of each species calculated on the basis of the total dinocyst sum including unidentified taxa and excluding pre-Quaternary specimens. Palynomorph absolute concentrations (number of dinocysts $/ \mathrm{cm}^{3}$ ) were calculated using the marker grain method (Stockmarr, 1971; de Vernal et al., 1999; Mertens et al., 2009).

A composite sequence was built (for what we have called the "SHACK area", i.e. green circle on Figure 1) using relative abundances of dinocysts from the twin cores SU81-18 (MIS 1 to 
2), MD95-2042 (MIS 2 to 6) and IODP 339 Site U1385 (MIS 11 and 19, "Shackleton site" sensu Hoddel et al., 2013a). A Principal component analysis (PCA) was applied to this raw data set (non- transformed relative abundances) using the XLSTAT software (XLSTAT Version 2015.4.01.19992 @Addinsoft 1995-2015, http://www.xlstat.com/en/). The training dataset and the PCA results can be downloaded on line as Supplementary information (SI). Additionally, some coherency tests were done using the XLSTAT and PAST (Hammer et al., 2001) softwares for the comparison of thermophilous indexes derived from pollen (Mediterranean forest) and from dinocysts. Two indexes were used for dinocysts: (a) the

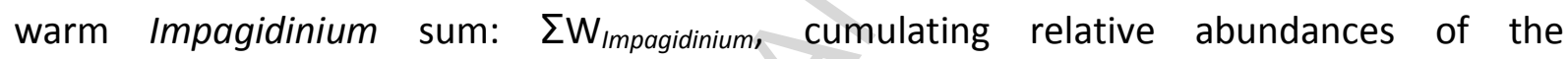
tropical/subtropical I. patulum and I. aculeatum species and of the subtropical/temperate $I$. paradoxum and I. sphaericum species; (b) the warm/ cold dinocyst ratio as defined in Combourieu-Nebout et al. (1999), i.e. $[\mathrm{W} /(\mathrm{W}+\mathrm{C})]$, where (W) cumulates warm-water indicator species: i.e. Spiniferites mirabilis s.I. (= S. mirabilis + S. hyperacanthus), Selenopemphix nephroides, Impagidinium patulum, Impagidinium strialatum, Operculodinium israelianum, Spiniferites delicatus, and Spiniferites membranaceus, excluding Operculodinium centrocarpum considered to be too ubiquitous, whereas (C) gathers coldwater indicators, namely: Nematosphaeropsis labyrinthus, Bitectatodinium tepikiense, Spiniferites elongatus, Impagidinium pallidum, Pentapharsodinium dalei and Islandinium minutum.

\section{Trends and common features in dinocyst communities during climatic optima and their transitions}


For the following discussion, we consider the main features detected in the assemblages over time. Our interpretations are based on dominant dinocyst species and also, in some cases, on biostratigraphically significant ones. A detailed picture of selected significant dinocyst species is provided for the SHACK area (MD95-2042/SU81-18 and IODP 339; Figure 2) since MIS 11 (from 410-384 ka) and MIS 19 (788-749 ka) analyses constitute new dinocyst results for this area.

The compilation made for the Southern Iberian margin is mainly based on the comparison of three specific/index groups, that dominate alternatively dinocyst assemblages and showed a sensitive response to climate shifts through time (Figure 3): i) heterotrophic taxa (sum established after the taxa list of Marret and Zonneveld, 2003), ii) warm Impagidinium species (sum of subtropical $I$. patulum and $I$. aculeatum species, also grouped with temperate $I$. paradoxum and I. sphaericum species), and iii) the species L. machaeorophorum.

In the SHACK area, autotrophic taxa are marked by the dominance of well-known temperate to cosmopolite species: Lingulodinium machaeorophorum, Nematosphaeropsis labyrinthus, Operculodinium centrocarpum sensu Wall and Dale (1966), cysts of Pentapharsodinium dalei together with numerous species from the Spiniferites group, including S. mirabilis s. I. and S ramosus s. s. (Figure 2). Heterotrophic dinocysts are mainly represented by Brigantedinium species (B. cariacoense and B. simplex included) together with Peridinioid taxa such as Selenopemphix quanta or Selenopemphix nephroides (Plate 1). In this group, it is worth noting the common occurrence of cysts of Protoperidinium stellatum, which will herein be refer to the usual binomial name "Stelladinium stellatum" (Plate 1) for practical reasons and in order to be consistent with reference recent works (e.g. Zonneveld et al., 2013) and with the Sprangers et al. (2004) dinocyst inventory study from modern sediments of the Iberian 
margin. In the MIS 19 section of IODP339 1385, S. stellatum abundances reach up to $7 \%$ of the total dinocyst assemblage (Figure 2), while this taxa was not observed in any of the most recent interglacials MIS 11, 5 and 1 from the twin cores MD95-2042 and SU81-18 (Eynaud, 1999; Turon et al., 2003). A similar assemblage pattern was also observed for the Alboran site ODP976 over a longer time scale (see Fig.2 in Combourieu-Nebout et al., 1999), with also an almost disappearance of S. stellatum for time periods following the Mid-Brunhes Event (MBE). On the basis of our compilation, the highest occurrences of S. stellatum observed during MIS 19 (between roughly 750 and 800 ka BP) could thus sign a specific biostratigraphic event. At present, this species is characteristic of hypertrophic environments and was used as a marker of eutrophication in historical times (e.g. Shin et al., 2010 in the East China and Japan seas; Zonneveld et al., 2012 in the Adriatic and Ionan seas). Furthermore, on the basis of sediment trap analyses from the Mauritanian upwelling zone, Zonneveld et al. (2010) related the ecology of S. stellatum and its seasonal dynamics to those of L. machaeorophorum. It has also been described from modern sediments of the Gulf of Mexico (Limoges et al., 2013), in Brittany Bays (Larrazabal et al., 1990), and identified as a potential proxy of sea-level rise over the last glacial-interglacial period by marked increases of this species detected at $16 \mathrm{ka}$ BP in near-equatorial latitudes of the Western African margin (Hardy et al., in prep).

Among the Spiniferites species, S. ramosus and the rare taxa S. rubinus (e.g. Harland, 1992; Head et al., 1996) also display noticeable biostratigraphic trends in relation to MIS 19: Between 750 and $800 \mathrm{ka}$, S. ramosus shows percentages two times higher than modern values recorded in the area (e.g. Rochon et al., 1999), and then shows a progressive decline until present (Figure 2 and 4). S. rubinus appears as specifically related to the beginning of MIS 19. Their cumulative abundances reached up to $30 \%$ of the assemblage at $784 \mathrm{ka}$. 


\subsection{L. machaeorophorum and heterotrophic dinocysts: when past data put to test modern ecology knowledge}

Figure $3 a$ provides an integrated peri-Iberian picture of dinocyst specific changes that occurred during interglacials and subsequent glacials in order to identify coherent ecological adaptations of this group through time. Climate changes are illustrated in parallel through planktonic $\delta^{18} \mathrm{O}$ signals obtained on the same cores (when available), the global LR04 benthic stack (Lisiecki and Raymo, 2005), and summer insolation values at $65^{\circ} \mathrm{N}$ (Berger and Loutre, 1991).

Especially obvious in all studied records is the opposition observed between the occurrence of heterotrophic dinocysts and L. machaeorophorum, which seem to exclude each other. Except during MIS 1, these two species show opposite patterns with the expansion of heterotrophic species during cold periods (percentages $\geq 80 \%$ reached during the last glacial) and of L. machaeorophorum during transitional periods (comparable high near monospecific values only recorded during glacial inceptions). This is especially evident for MIS 19, 11 and 5 but should be shaded for MIS 1 where the L. machaerophorum high abundances occur early just after the Termination I. The species L. machaerophorum (related to the motile dinoflagellate Lingulodinium polyedrum) is a widely distributed dinocyst (e.g. Rochon et al., 1999) but is especially concentrated today in coastal/neritic sediments around the Gibraltar strait (Williams, 1971; Marret and Zonneveld, 2003; Zonneveld et al., 2013; Penaud et al., in prep). This local high occurrence is particularly interesting as this species could then be used as a peculiar taxa index for the present study. L. machaerophorum also colonizes estuarine 
environments (Morzadec-Kerfourn, 1977, 1992) and is frequently associated with eutrophic areas (fjords especially, e.g. Sætre et al., 1997, Dale et al., 1999, but not restrictively e.g. Zonneveld et al., 2012). As such, Leroy et al. (2013) recently considered its highest occurrences in the Caspian Sea as a biostratigraphical marker for the Anthropocene. Finally, it was interpreted as a proxy for past huge river discharges into the Ocean (Zaragosi et al., 2001; Eynaud et al., 2007; Penaud et al., in prep) and even considered as allochtonous in marine waters by Turon and Londeix (1988). Blooms of its motile form can be responsible for toxic red tides (Moorthi et al., 2006) and some culture experiments demonstrated that this species is highly sensitive to the water column stratification (Thomas and Gibson, 1990; 1992).

At present, L. machaerophorum distribution in modern sediments matches fairly well with the distribution of heterotrophic species, with high abundances preferentially found in coastal regions and close to upwelling cells (e.g. Zonneveld et al., 2013). It questions the observed patterns in our records where these species rather seem to oppose: (1) are they related to nuanced ecological patterns such as seasonality, i.e. shifts from permanent to seasonal upwelling regimes (or vice-versa) which could have induced major changes in dinocyst communities, or (2) are they due to preservation and/or cyst transportation changes along time? Preservation is especially a critical issue as dinocyst species are not equally impacted by oxydation in the water-column and after deposition (e.g. Zonneveld et al., 1997, 2012; Zonneveld and Brummer, 2000; Bogus et al., 2012): some of them being very sensitive to water oxygen concentrations and thus water sources and dynamics. It is generally accepted that brown cysts, mainly produced by heterotrophic dinoflagellates (i.e. Protoperidinium) are more sensitive to aerobic degradation than Gonyaulacoid derived cysts (e.g. Dale, 1976). Among our index taxa for this comparative study, L. machaerophorum and 
warm Impagidinium species are respectively classified as moderately sensitive and resistant to oxygen availability in bottom waters (de Vernal and Marret, 2007).

Does the observed pattern thus signify a difference in bottom water-mass properties (and thus circulation) rather than a sea-surface productivity change, or is it a combination of both processes? In our study, the inter-basin comparison can provide some clues to solve this question, as the opposition between heterotroph cysts and L. machaerophorum are systematically observed whatever the considered period and basin. Such a coherent pattern suggests a similar way of cyst production and/or preservation despite distinct local surface and bottom conditions. It is highly improbable that interglacial/ glacial changes cancelled these hydrographical differences since dinocyst population changes are not perfectly synchronized between the two basins, thus also underlining their own specificities through time. Therefore, the alternative solution would be to consider that the observed downcore antiphase between heterotroph cysts and L. machaerophorum is not a matter of postproduction/preservation biases. Then, how to reconcile quite similar modern biogeographies which, in past times, seemed to exclude each other? Modern L. machaerophorum ecological requirements are still far from being correctly identified and this species may represent simply an opportunistic species. Interestingly, L. machaerophorum dynamics observed from our compilation (Figure 3) reveals that this species follows or precedes maximal expansion of warm sea-surface taxa during interglacial optima. This shift is then discussed below.

\subsection{Warm Impagidinium species along interglacials: what do they reveal?}


In this study, the probable most significant dinocyst assemblage we retained is the one associated with Impagidinium. These typical oceanic taxa, often thermophilous, are among the common dinocysts found in the area (e.g., Turon et al., 2003; Penaud et al., 2011). For this work, we have lumped together abundances of warm Impagidinium ( $\left.\Sigma W_{\text {Impagidinium }}\right)$ to define a specific index of warm sea-surface conditions ,for which we have tested coherency through time and from one basin to another (Figure 3 and 4, see also SI for further details regarding this group). At present, maximum abundances of these species are recorded in sediments of the equatorial Atlantic Ocean with a preference for full marine waters (Zonneveld et al., 2013). In the studied records, highest $\Sigma W_{\text {Impagidinium }}$ values (i.e. $>10 \%$ ) are associated with the onset of warm conditions during climatic optima (as defined from low isotopic values plateau, Figure 3a). Their expansion is noticeable during short periods only, of maximum duration of $10 \mathrm{ka}$, in close phasing with negative shifts in the planktonic $\delta^{18} \mathrm{O}$ signal. They seem specifically to mark post-glacial warm conditions rather than hypsithermal periods (Figure 3). The relative short duration of expansion of these warm Impagidinium is easily explained by competition stress with other thermophilous taxa such as S. mirabilis (see Turon and Londeix, 1988; Eynaud et al. 2000, Penaud et al., 2008, 2011 for discussions). It could also typify a peculiar ecological strategy as a pioneer group and/or as accompanying a change in the oceanic circulation as it was already suggested by Londeix et al. (2007).

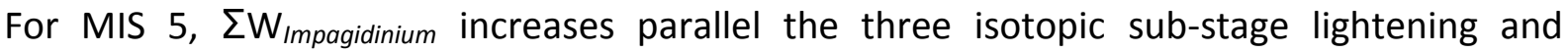
coincide well with insolation maxima (pink bands on Figure 3a). When comparing the intrinsic dynamics of each interglacial optima in the SHACK area (Figure 3b) by synchronizing Terminations (here Terminations I, II and IX after Lisiecki and Raymo, 2005), and despite differences in temporal resolution analysis, trends in the $\Sigma W_{\text {Impagidinium }}$ show similar pacing 
along interglacials. This is especially obvious for peaks observed just after Terminations and for the glacial inception following interglacial optima.

Furthermore, the multi-phased interglacial complexes MIS 19 and MIS 5 are also well reflected in the $\Sigma W_{\text {Impagidinium }}$ evolution. Amplitudes for MIS 1 (green curve; Figure $3 \mathrm{~b}$ ) are noticeably largest than those of previous warm MIS (blue and red curves; Figure 3b), probably resulting from a major dinocyst community change through time, implying a growing presence of Impagidinium species associated with a synchronous general decline of Spiniferites species (as previously pointed out).

Figure 4 synthesizes the most salient features provided by dinocysts and pollen (here the Mediterranean forest) for a composite sequence consisting of cores SU81-18 (e.g. Turon et al., 2003), MD95-2042 (e.g. Eynaud et al. 2000; Shackleton et al., 2003) and IODP 3391385 (this work, Sànchez-Goni et al., this volume). Additionally we plotted alkenone-derived SST from core MD95-2042 (MIS 1 and 5 sections after Pailler and Bard, 2002) and from the proximal core MD01-2443 (MIS 11 section after Martrat et al., 2007). Percentages of the polar taxa Neogloboquadrina pachyderma sinistral (Nps) are also shown (from core SU81-18 MIS 1 after Turon et al., 2003, for core MD95-2042 MIS 5 after Sànchez-Goñi et al., 2006; for core MD01-2443 MIS 11 after Voelker and de Abreu, 2011). This data set is also compared to the Marine $\delta^{18} \mathrm{O}$ stack LRO4 (Lisiecki and Raymo, 2005) and to summer insolation at $65^{\circ} \mathrm{N}$ (Berger and Loutre, 1991). Periods of maximum values of $\Sigma W_{\text {Impagidinium }}$ are marked by pink bands. They provide evidence of discrete warming episodes that took place near Terminations I, II and IX, that we can also directly compare with synchronous proximal continental responses regarding Mediterranean forest evolution. From this compilation, sea- 
surface warming events appear synchronous with warming detected on land at millennial scales. A test of correlation was done to check this synchronicity giving a $r^{2}$ of 0.270 (results obtained with the Past software, see SI). The reader should keep in mind that pollen and dinocyst preparations are observed from same slides, coming from identical laboratory procedures, thus implying no artefact when correlating palynological ocean-continent data. Such a result confirms previous observations made for MIS 5 and 3 on the same site (Sànchez-Goñi et al., 1999, 2000; Eynaud et al., 2000) and permits us here to confirm and extend the continental / ocean relationship up to $800 \mathrm{ka}$.

In contrast to $\Sigma \mathrm{W}_{\text {Impagidinium, }}$ high abundances of Bitectatodinium tepikiense are observed during cold phases, also characterized by high Nps percentages. A strong representation of B. tepikiense is especially noticeable during cold MIS 5 interglacial substages. Cold phases are also marked by high absolute abundances of dinocysts (i.e. concentrations in nb of cysts / dry $\mathrm{cm}^{3}$ ) in sediments. These high concentrations were already noted by several authors on this margin during cold climatic events (e.g. Zippi, 1992; Eynaud, 1999; Eynaud et al., 2009; Penaud et al., 2010; 2011) and interpreted as representing changes in the local upwelling dynamics (from seasonal to year-round) in response to atmospheric re-organisations. This interpretation was based on the distribution of modern dinocyst concentrations in the sediments from the proximal North Canary Basin, which show high dinocyst concentrations within zones marking upwelling filaments (e.g. Targarona et al., 1999; Bouimetarhan et al., 2009b). Conversely, on the SW Iberian Margin (Figure 1), Zippi (1992) noted an opposite relation between carbonate content and dinocyst concentrations in the sediment and attributed that observation to the preferential dissolution of carbonate under cold climate (and thus the artificial increase of cysts) in concordance to a high index of fragmentations of planktonic foraminifera shells. However, Zippi (1992) did not introduce any consideration 
about the paleoproductivity issue. Indeed, for calcareous (foraminifera) as well as for organic-walled (dinocysts) material, the residual concentration of microfossils in sediments is the result of a complex balance between production, dissolution and preservation. Thanks to the close correlation made in this study between marine and pollen data, we directly attribute the modulation of dinocyst concentrations to climate.

\section{The significance of population shifts: from ecology to oceanic circulation patterns}

The dinocyst compilation made in this study provides important biodiversity information that could be tied to changes in the local and/or regional hydrographical dynamics in response to climate changes. Population shifts occur repetitively and coherently through time with some index groups that could be used to evaluate the adaptation capability of the marine flora. They illustrate a constant population interchange between the western Mediterranean and the subtropical North Atlantic despite sea-level changes and the temporal physiographic barrier of the Strait of Gilbraltar, which should have reduced water exchanges during low sea-levels of the last million years. These latter processes have had important echoes on planktonic populations, as demonstrated by Rohling et al (1995) for planktonic foraminifera, something also detected with some dinocyst key taxa.

Strong modulations of the MOW have already been pointed out by several studies for the last glacial (e.g. Cacho et al., 2000; Voelker et al., 2006; Rogerson et al., 2010), showing an acceleration of the outflow during cold phases. Their impact on the distribution of dinoflagellate and their cysts has certainly been important. A southward migration of 
biogeographical provinces in the North Atlantic and even the invasion of the Alboran Sea waters by $B$. tepikiense from where this species is absent at present (Turon and Londeix, 1988; Combourieu-Nebout et al., 2002; Penaud et al., 2011; Figure 3) have been observed concomitantly. This invasion, in a configuration of accelerated MOW, attests to an extensive North Atlantic intrusion in the Alboran Sea, probably as a way to compensate the MOW export and its associated deficit. This thus supposes vigorous Atlantic/Mediterranean exchanges at those times and thus enhanced exportation/importation of cysts.

Cold sub-stages within interglacial complexes (MIS 19 and 5) demonstrate the same biotic pattern with also high occurrences of B. tepikiense (this work, Combourieu Nebout et al., 1999; Eynaud et al., 2000). The context is however different here even if some analoguous hydrographical mechanisms could be at play, i.e. due to acceleration of the MOW also, but in this case rather forced by a reduction of the Gibraltar strait section during cold sub-stages and associated sea-level low stands (the reader should keep in mind that at the opposite HEs record a rising sea-level with an estimated magnitude of up to $30 \mathrm{~m}$, e.g Siddal et al., 2003). The synchronous regression of warm species and of $L$. machaerophorum furthermore documents a severe cooling and a major change of the water column stability; a vital requirement for this later species as deduced from culture (e.g. Thomas and Gibson, 1990). Turbulence at the Gibraltar strait due to the acceleration of currents, thus preventing a soft settling of cysts and inhibiting a complete life cycle, could explain the L. machaerophorum disappearance. This turbulence could be amplified by atmospheric processes, i.e. winds, the regression of the Mediterranean forest on Iberia being also noticed (Figure 3).

The past population shifts observed in this part of the sub-tropical North-Atlantic provide some new insights regarding the known modern ecology and biogeography of cysts and their 
related theca (i.e. Marret and Zonneveld, 2003, de Vernal and Marret, 2007). They show a strong potential for dinoflagellates to adapt, even when facing abrupt ecological changes. Two taxa would especially be considered as super-adapted to transient periods: one is a common typical cyst from the studied area, L. machaerophorum; the other, B. tepikiense, is a taxa rather distributed in the cool temperate Atlantic but especially adapted to strong seasonality (i.e. cold winters and warm summers), as those which characterize waters from the St Laurent outlet at present (e.g. Rochon et al., 1999). These two species are found at the transition boundaries of interglacial optima and could thus be qualified of opportunistic, as conditions accompanying transition phases (glacial inception and termination) are especially unstable and contrast with the relative equilibrium of warm optima. However the local high occurrence of $L$. machaerophorum rather argues for a pre-adaptation to the seasurface conditions surrounding the Gibraltar strait. Conversely, its presence with nearly mono-specific abundances in the modern sediments from the Iberian and North Canary regions since $5 \mathrm{ka}$ at least (Figure 2) questions the hydrographic and associated climatic modes of the last millennia. When comparing its specific dynamics during previous interglacials, this species does not mark hypsithermal modes but rather cooler conditions. This supports previous findings showing that modern conditions around Iberia already shifted toward a late Holocene Neoglacial state (e.g. Jerardino, 1995). For the Atlantic side, it seems to have already implied changes in the seasonality of the modern Canary Current upwelling (e.g. Abrantes et al., 2011; Mc Gregor et al., 2007; Bouimetarhan et al., 2009a). 


\section{The nine past and current interglacials: new insights from dinocyst data of the "Shackleton" site}

Even if not continuous, the dinocyst data produced for this compilation gathering cores from the SHACK area (Figure 1) offer the possibility to test the significance of this phytoplanktonic population regarding long term records over the last $800 \mathrm{ka}$. The purpose of our approach was to test interglacial periods in low eccentricity contexts first, explaining why, up to date, our focus and records are thus restricted to some snapshots. To present a comprehensive view of these results and simplify the message brought by dinocyst assemblages, we ran a PCA on the composite "SHACK" sequence (SU81-18 /MD95-2042 /IODP339 U1385, see methods and SI). The coordinates of the first three axis obtained from this PCA are plotted along time on Figure 5 and compared to selected 800 ka-long-sequences of interest, along with the $[\mathrm{W}(/(\mathrm{C}+\mathrm{W})]$ dinocyst ratio for the SHACK area and for the Alboran ODP976 record which, even if of lowest resolution, encompasses the last $810 \mathrm{ka}$ (Combourieu-Nebout et al., 1999). A schematic index reflecting qualitatively the Aguhlas linkage dynamics (as redrawn from Caley et al. 2012) is also plotted to further document inter-oceanic exchanges.

This comparison reveals very distinctive patterns and specific signatures (Figure 5 and $\mathrm{SI}$ ) for each of the first three PCA-axis (these 3 axis representing nearly $30 \%$ of the total variance, see methods and the excel file provided in SI for detailed results of the PCA). These signatures could be summarized as follow: (a) a first axis F1 (13.6 \% of the total variance), positively related to warm eutrophic species but negatively related to cold eutrophic ones (see species/variables distribution in SI), thus bearing the double and coupled environmental signal of SST and upwelling dynamics. Considering a paleoceanographic 
perspective, this axis clearly relates to global changes as seen throughout the (ice-volume/ sea-level linked) LRO4 record and the $\mathrm{CO}_{2}$ atmospheric content.

(b) a second axis F2 (7.65 \% of the total variance), also bearing a strong SST/ upwelling signature but for which species positively correlated to, are representative of the typical Iberian margin modern dinocyst assemblage (i.e. Sprangers et al, 2004). Its time distribution shows a close matching with the Ca content (vs terrigeneous components) of marine sediments from the subtropical North Atlantic western margin as derived from XRF data, both for the same "Shackleton site" (Log (Ti/ Ca) from Hoddel et al., 2013a and b) and from the southern core MD03-2705 (Malaizé et al., 2012).

(c) a third axis F3 (7.33\% of the total variance), which plainly separates autotrophic from heterotrophic dinocyst species, and is interestingly closely mirroring the monsoon index along time (after the stack produced by Clemens et al., 2008).

From this 810 ka long perspective, arise some noticeable points which shed light on the high sensitivity of dinocyst communities regarding climate changes. First of all, it is worth noting the good reproducibility of the $[\mathrm{W}(/(\mathrm{C}+\mathrm{W})]$ ratio at the regional scale except during MIS 19 where the "Shackleton site" reveals much more contrasted responses. Differences in time resolution are at the origin of this discrepancy but other evidences are brought by the PCA that this MIS 19 interval is clearly atypical. This is well expressed in the F1 component which registers large and sharp amplitude shifts (not seen later in the Pleistocene neither in the Holocene) and additionally shows poor matching with other 810 ka records as plotted on Figure 5. Conversely, F2 and F3 during MIS 19 closely mirror the Ca sedimentary content and the monsoon index respectively, recording synchronous and consistent transitions, thus suggesting that the message brought by dinocyst populations from the Iberian margin is however comprehensive enough to be assimilated to large scale environmental changes 
over the last $810 \mathrm{ka}$. The link between the Ca content and PCA axis 2 is easily understandable at the scale of the North Atlantic basin (including its marginal seas) as it reflects mainly biogenic carbonate content and thus the pelagic production, well known to be favoured, during warm periods (e.g. Chapman and Shackleton, 1997; Richter et al., 2007; Hodell et al., 2013b). In the same way, consistency between the stacked monsoon index vs the PCA axis 3 could be explained by the fact that this axis is mainly representing the weight of autotrophic species which thereby need sea-surface fertilisation and thus dust arrival to proliferate. Most problematic is the signal detected with the PCA axis 1 during MIS 19, which if it does echo the $[W(/(C+W)]$ ratio and the Ca content within the "Shackleton site", is not completely attributable to long term and global trends as stated previously. Is this difference related to the specific assemblage we encountered during MIS 19, with the occurrence of atypical species such as S. stellatum and S. rubinus, and the high percentages of S. ramosus as previously underlined? Could the drastic climatic transitions occurring between MIS 19 and modern times, i.e. the MPT and the MBE, have impacted dinocyst population of this area so significantly? This is highly possible, as these two climatic temporal nodes are known to sign major oceanic reorganisations, with especially a strong impact on the Atlantic meridional oceanic circulation (e.g. Poirier and Billups, 2014; Bell et al.,2015), a key component for the Iberian margin oceanography and its associated upwelling dynamics. To valid such an assumption we urgently need to further extend our record up and back in time, putting a focus not only on past interglacials but also on glacials, including the atypical MIS 13 and MIS 6 ones, so as to detect an optimal set of contrasted features.

\section{Conclusions}


This study was designed to provide new biogeographical and stratigraphical patterns for the Iberian margin by compiling micropaleontological records derived from the study of dinoflagellate cysts during past interglacials. This effort has revealed that surface waters around Iberia were characterised over the last million years by the repetitive occurrence of the same dinocyst assemblage; however, some discrepancies in the response of this marine protist community shade its adaption to glacial and interglacial cycles. Very coherent features occur on both sides of the Gibraltar strait indicating a constant interchange of populations and a permanent connection between Atlantic and Mediterranean marine biomes, even during sea-level low stands. Regarding dinocysts, this interchange is easily attributed to sea-surface water exchanges, but the Mediterranean Outflow Waters could also be considered as a vector of settled cysts. Some index groups could be used to evaluate the adaptation capability and the dynamics of the marine dinoflagellate flora, especially the autotrophic cysts: Lingulodinium machaerophorum, Bitectatodinium tepikiense, together with some species from the Spiniferites and the Impagidinium groups, which swing with heterotrophic dinocysts along time. Changes detected in the dinocyst community appeared to be coherent at sub-orbital and orbital scales with those detected with other sea-surface proxies and continental bio-indicators (pollen), demonstrating a close connection between sea-surface environments and the Iberian continent over the last $800 \mathrm{ka}$.

\section{Acknowledgements}

The crews, together with the scientific and technical staffs of the RV JOIDES Resolution are thanked for work accomplished during the IODP leg 339 and the recovery of site U1385. This 
study was conducted in the frame of the INSU (OA-LEFE-IMAGO and TS-INTERRVIE) French CNRS programs within the "IceBioRAM", "Warmclim" \& "Pulse" projects and grants which supported palynological analyses of the IODP339 U1385 site. We wish to thank L. Devaux for preparing the samples and MC Gasparotto for her help on MIS 11 data acquisition. We gratefully acknowledge reviewers, whose anonymous comments have contributed to increase the quality of this manuscript. This is an UMR-EPOC contribution.

\section{Supplementary data}

Supplementary data associated with this article can be found in the online version, at ...

\section{References}

Abrantes, F., Rodrigues, T., Montanari, B., Santos, C., Witt, L., Lopes, C., Voelker, A., 2011. Climate of the last millennium at the southern pole of the North Atlantic Oscillation: an inner-shelf sediment record of flooding and upwelling. Climate Research 48, 261-280. doi:10.3354/cr01010

Arístegui, J., Ãlvarez-Salgado, X.A., Barton, E.D., Figueiras, F.G., Hernandez-Leon, S., Roy, C., Santos, A.M.P., 2005. Oceanography and fisheries of the canary current/ Iberian region of the eastern north Atlantic (18a, E), in: The Sea. Allan R. Robinson and Kenneth H. Brink. 
Arístegui, J., Barton, E.D., Álvarez-Salgado, X.A., Santos, A.M.P., Figueiras, F.G., Kifani, S., Hernández-León, S., Mason, E., Machú, E., Demarcq, H., 2009. Sub-regional ecosystem variability in the Canary Current upwelling. Progress in Oceanography 83, 33-48. doi:10.1016/j.pocean.2009.07.031

Bell, D.B., Jung, S.J.A., Kroon, D., 2015. The Plio-Pleistocene development of Atlantic deepwater circulation and its influence on climate trends. Quaternary Science Reviews 123, 265282. doi:10.1016/j.quascirev.2015.06.026

Bogus, K.A., Zonneveld, K.A.F., Fischer, D., Kasten, S., Bohrmann, G., Versteegh, G.J.M., 2012. The effect of meter-scale lateral oxygen gradients at the sediment-water interface on selected organic matter based alteration, productivity and temperature proxies. Biogeosciences 9, 1553-1570.

Bouimetarhan, I., Dupont, L., Schefuß, E., Mollenhauer, G., Mulitza, S., Zonneveld, K., 2009a. Palynological evidence for climatic and oceanic variability off NW Africa during the late Holocene. Quaternary Research 72, 188-197. doi:10.1016/j.yqres.2009.05.003

Bouimetarhan, I., Marret, F., Dupont, L., Zonneveld, K., 2009b. Dinoflagellate cyst distribution in marine surface sediments off West Africa $\left(17-6^{\circ} \mathrm{N}\right)$ in relation to sea-surface conditions, freshwater input and seasonal coastal upwelling. Marine Micropaleontology 71, 113-130. doi:10.1016/j.marmicro.2009.02.001

Cacho, I., Grimalt, J.O., Sierro, J.F., Shackleton, N., Canals, M., 2000. Evidence for enhanced Mediterranean thermohaline circulation during rapid climatic coolings. Earth and Planetary Science Letters 183, 417-429. 
Caley, T., Giraudeau, J., Malaizé, B., Rossignol, L., Pierre, C., 2012. Agulhas leakage as a key process in the modes of Quaternary climate changes. Proceedings of the National Academy of Sciences 109, 6835-6839.

Candy, I., Coope, G.R., Lee, J.R., Parfitt, S.A., Preece, R.C., Rose, J., Schreve, D.C., 2010. Pronounced warmth during early Middle Pleistocene interglacials: Investigating the MidBrunhes Event in the British terrestrial sequence. Earth-Science Reviews 103, 183-196. doi:10.1016/j.earscirev.2010.09.007

Chapman, M.R., Shackleton, N.J., 1999. Global ice-volume fluctuations, North Atlantic icerafting events, and deep-ocean circulation changes between 130 and 70ka. Geology 27, 795798.

Clemens, S.C., et al. 2008. Plio-Pleistocene East Asian Monsoon Proxy Data. IGBP PAGES/World Data Center for Paleoclimatology Data Contribution Series \# 2008-119. NOAA/NCDC Paleoclimatology Program, Boulder CO, USA.

Combourieu-Nebout, N., Londeix, L., Baudin, F., Turon, J.-L., von Grafenstein, R., Zahn, R., 1999. Chap. 36: Quaternary marine and continental paleoenvironments in the western Mediterranean (site 976, Alboran sea): palynological evidence. Zahn, R., Comas, M.C., and Klaus, A. (Eds.), Proceedings of the Ocean Drilling Program Scientific Results 161. pp. 457468.

Combourieu-Nebout, N., Paterne, M., Turon, J.-L., Siani, G., 1998. A high resolution record of the last deglaciation in the central Mediterranean sea: palaeovegetation and palaeohydrological evolution. Quaternary Science Reviews 17, 303-317. 
Combourieu-Nebout, N., Turon, J.-L., Zahn, R., Capotondi, L., Londeix, L., Pahnke, K., 2002. Enhanced aridity and atmospheric high-pressure stability over the western Mediterranean during the North Atlantic cold events of the past 50 k.y. Geology 30, 863-866.

Crutzen, P.J., 2002. The "anthropocene." J Phys. IV France, EDP Sciences, Les Ulis 12. doi:IO.10511jp4:20020447

Dale, B., 1976. Cyst formation, sedimentation, and preservation: factors affecting dinoflagellate assemblages in recent sediments from Trondheimsfjord, Norway. Rev. Palaeobot. Palynol. 22, 39-60.

Dale, B., 1983. Dinoflagellate resting cysts: "benthic plankton". In "Survival strategies of the algae" Greta A. Fryxell (ed.). p 69- 1367 Cambridge University Press

Dale, B., Thorsen, T.A., Fjellsa, A., 1999. Dinoflagellate Cysts as Indicators of Cultural Eutrophication in the Oslofjord, Norway. Estuarine, Coastal and Shelf Science 48, 371-382.

De Schepper, S., Groeneveld, J., Naafs, B.D.A., Van Renterghem, C., Hennissen, J., Head, M.J., Louwye, S., Fabian, K., 2013. Northern Hemisphere Glaciation during the Globally Warm Early Late Pliocene. PLoS ONE 8, e81508. doi:10.1371/journal.pone.0081508

de Vernal, A., Henry, M., Bilodeau, G., 1999. Techniques de préparation et d'analyse en micropaléontologie. Les cahiers du GEOTOP 3, 1-29.

de Vernal, A., Londeix, L., Mudie, P.J., Harland, R., Morzadec-Kerfourn, M.-T., Turon, J.L., Wrenn, J.H., 1992. Quaternary organic-walled dinoflagellate cysts of the North Atlantic Ocean and adjacent seas: ecostratigraphy and biostratigraphy, in: Head, M.J., 
Wrenn, J.H. (Eds.), Neogene and Quaternary Dinoflagellate Cyst of the North Atlantic Ocean and Adjacent Seas : Ecostratigraphy and Biostratigraphy. AASP Foundation, pp. 289-328.

de Vernal, A., Henry, M., Matthiessen, J., Mudie, P.J., Rochon, A., Boessenkool, K.P., Eynaud, F., Grösfjeld, K., Guiot, J., Hamel, D., Harland, R., Head, M.J., Kunz-Pirrung, M., Levac, E., Loucheur, V., Peyron, O., Pospelova, V., Radi, T., Turon, J.L., Voronina, E., 2001. Dinoflagellate cyst assemblages in surface sediments of the Laptev Sea region (Arctic Ocean) and their relationship to hydrographic conditions. Journal of Quaternary Science 16, 637649.

de Vernal, A., Marret, F., 2007. Chapter Nine : Organic-Walled Dinoflagellate Cysts : Tracers of Sea-Surface Conditions., in: Hillaire-Marcel, C., de Vernal, A. (Eds.), Developments in Marine Geology. pp. 371-408.

Dodge, J.D., Harland, R., 1991. The distribution of planktonic dinoflagellates and their cysts in the eastern and northeastern Atlantic Ocean. New Phyto. 118, 593-603.

Ellegaard, M., Figueroa, R., Versteegh, G.J.M., 2013. Dinoflagellate Life Cycles, Strategy and Diversity: Key Foci for Future Research, in: Lewis, J. M., Marret, F. \& Bradley, L. (eds) 2013. Biological and Geological Perspectives of Dinoflagellates. The Micropalaeontological Society, Special Publications. Geological Society, London, pp. 249-261.

Eynaud, F., 1999. Kystes de Dinoflagellés et Evolution paléoclimatique et paléohydrologique de l'Atlantique Nord au cours du Dernier Cycle Climatique du Quaternaire (Thèse de 3e cycle). Université de Bordeaux I.

Eynaud, F., De Abreu, L., Voelker, A., Schönfeld, J., Salgueiro, E., Turon, J.L., Penaud, A., Toucanne, S., Naughton, F., Sànchez-Goñi, M.F., Malaizé, B., Cacho, I., 2009. Position of the 
Polar Front along the western Iberian margin during key cold episodes of the last $45 \mathrm{ka}$. Geochemistry, Geophysics, Geosystems 10. doi:10.1029/2009GC002398

Eynaud, F., Turon, J.L., Sànchez-Goñi, M.F., Gendreau, S., 2000. Dinoflagellate cyst evidence of "Heinrich-like events" off Portugal during the Marine Isotopic Stage 5. Marine Micropaleontology 40, 9-21.

Eynaud, F., Zaragosi, S., Scourse, J.D., Mojtahid, M., Bourillet, J.F., Hall, I.R., Penaud, A., Locascio, M., Reijonen, A., 2007. Deglacial laminated facies on the NW European continental margin: The hydrographic significance of British-Irish Ice Sheet deglaciation and Fleuve Manche paleoriver discharges. Geochemistry, Geophysics, Geosystems 8.

Fensome, R.A., MacRae, R.A., Williams, G.L., 1998. DINOFLAJ. Geological Survey of Canada Open File 3653.

Fensome, R.A., Williams, G.L., 2004. The Lentin and Williams index of fossil dinoflagellates, AASP Foundation Contributions Series 42, 909 pp. ed.

Figueroa, R.I., Bravo, I., 2005. Sexual reproduction and two different encystment strategies of Lingulodinium polyedrum (dinophyceae) in culture. Journal of Phycology 41, 370-379. doi:10.1111/j.1529-8817.2005.04150.x

Font, J., 2002. Mesoscale variability in the Alboran Sea: Synthetic aperture radar imaging of frontal eddies. Journal of Geophysical Research 107. doi:10.1029/2001JC000835

Giorgi, F., 2006. Climate change hot-spots. Geoph. Research Letters 33, L08707, doi:10.1029/2006GL025734 
Hammer, Ø., Harper, D.A.T., Ryan, P.D. 2001. PAST: Paleontological statistics software package for education and data analysis. Palaeontologia Electronica 4(1): 9pp. http://palaeoelectronica.org/2001_1/past/issue1_01.htm

Harland, R., 1992. Dinoflagellate Biostratigraphy of Neogene and Quaternary Sediments at Holes 400/400A in the Bay of Biscay (Deep Sea Drilling Project Leg 48). DSDP Initial Reports Volume XLVIII. doi:doi:10.2973/dsdp.proc.48.1979

Hauschildt, M., Rinna, J., Rullkötter, J., 1999. Chap. 30: Molecular Indicators of the supply of marine and terrigenous organic matter to a pleistocene organic-matter-rich layer in the Alboran Basin (Western Mediterranean Sea). Zahn, R., Comas, M.C., and Klaus, A. (Eds.), Proceedings of the Ocean Drilling Program Scientific Results 161. pp. 391-400.

Head, M.J., 1996. Modern dinoflagellate cysts and their biological affinities. Palynology: principles and applications 3, 1197-1248.

Heinrich, H., 1988. Origin and Consequences of Cyclic Ice Rafting in the Northeast Atlantic Ocean during the Past 130,000 Years. Quaternary Research 29, 142-152.

Hodell, D.A., Lourens, L., Stow, D.A.V., Hernández-Molina, J., Alvarez Zarikian, C.A., and the Shackleton site project members, 2013a. The "Shackleton Site" (IODP Site U1385) on the Iberian Margin. Scientific Drilling 16, 13-19. doi:10.5194/sd-16-13-2013

Hodell, D., Crowhurst, S., Skinner, L., Tzedakis, P.C., Margari, V., Channell, J.E.T., Kamenov, G., Maclachlan, S., Rothwell, G., 2013b. Response of Iberian Margin sediments to orbital and suborbital forcing over the past 420 ka. Paleoceanography 28, 185-199. doi:10.1002/palo.20017 
Hodell, D., Lourens, L., Crowhurst, S., Konijnendijk, T., Tjallingii, R., Jiménez-Espejo, F., Skinner, L., Tzedakis, P.C., 2015. A reference time scale for Site U1385 (Shackleton Site) on the SW Iberian Margin. Global and Planetary Change 133, 49-64. doi:10.1016/j.gloplacha.2015.07.002.

Houben, A. J.P., 2013. Multicompartment Mesoporous Silica Nanoparticles with Branched Shapes: An Epitaxial Growth Mechanism. Science 340, 341-344. doi:DOI: $10.1126 /$ science. 1223646

Jansson, I.-M., Mertens, K.N., Head, M.J., de Vernal, A., Londeix, L., Marret, F., Matthiessen, J., Sangiorgi, F., 2014. Statistically assessing the correlation between salinity and morphology in cysts produced by the dinoflagellate Protoceratium reticulatum from surface sediments of the North Atlantic Ocean, Mediterranean-Marmara-Black Sea region, and Baltic-KattegatSkagerrak estuarine system. Palaeogeography, Palaeoclimatology, Palaeoecology 399, 202213. doi:10.1016/j.palaeo.2014.01.012

Jerardino, A., 1995. Late Holocene Neoglacial episodes in southern South America and southern Africa: a comparison. The Holocene 5, 361-368.

Johnson, R.G., 1997. Ice age initiation by an ocean-atmospheric circulation change in the Labrador Sea. Earth and Planetary Science Letters 148, 367-379.

Kodrans-Nsiah, M., de Lange, G.J., Zonneveld, K.A.F., 2008. A natural exposure experiment on short-term species-selective aerobic degradation of dinoflagellate cysts. Review of Palaeobotany and Palynology 152, 32-39.

Lang, N., Wolff, E.W., 2011. Interglacial and glacial variability from the last 800 ka in marine, ice and terrestrial archives. Climate of the Past 7, 361-380. doi:10.5194/cp-7-361-2011 
Larrazabal, M.E., Lassus, P., Maggi, P., Bardouil, M., 1990. Kystes modernes de dinoflagellés en baie de Vilaine-Bretagne sud (France). Cryptogamie Algologie 11, 171-185.

Le coeur, Laurence, 1993. Reconstitution quantitative des paléotempératures et des paléosalinités de surface depuis le dernier maximum glacaire, au large du Portugal, à partir des asssemblages de kystes de dinoflagellés (DEA, U. Bordeaux 1, non publié).

Leroy, S.A.G., Lahijani, H.A.K., Reyss, J.-L., Chalié, F., Haghani, S., Shah-Hosseini, M., Shahkarami, S., Tudryn, A., Arpe, K., Habibi, P., Nasrollahzadeh, H.S., Makhlough, A., 2013. A two-step expansion of the dinocyst Lingulodinium machaerophorum in the Caspian Sea: the role of changing environment. Quaternary Science Reviews 77, 31-45. doi:10.1016/j.quascirev.2013.06.026

Levi, Camille, 1999. Les variations paléo-climatiques et paléo-hydrologiques en Méditerranée occidentale (Mer d'Alboran) entre -70000 et -130000 ans (Stade isotopique 5). (DEA Environnements et paléoenvironnements océaniques report, Univ. Bordeaux 1).

Lisiecki, L.E., Raymo, M.E., 2005. A Pliocene-Pleistocene stack of 57 globally distributed benthic $\delta 180$ records. Paleoceanography $20,1-17$.

Limoges, A., Londeix, L., de Vernal, A., 2013. Organic-walled dinoflagellate cyst distribution in the Gulf of Mexico. Marine Micropaleontology 102, 51-68. doi:10.1016/j.marmicro.2013.06.002

Londeix, L., Benzakour, M., Suc, J.-P., Turon, J.-L., 2007. Messinian palaeoenvironments and hydrology in Sicily (Italy): The dinoflagellate cyst record. Geobios 40, 233-250. doi:10.1016/j.geobios.2006.12.001 
Malaizé, B., Jullien, E., Tisserand, A., Skonieczny, C., Grousset, E.F., Eynaud, F., Kissel, C., Bonnin, J., Karstens, S., Martinez, P., Bory, A., Bout-Roumazeilles, V., Caley, T., Crosta, X., Charlier, K., Rossignol, L., Flores, J.-A., Schneider, R., 2012. The impact of African aridity on the isotopic signature of Atlantic deep waters across the Middle Pleistocene Transition. Quaternary Research 77, 182-191. doi:10.1016/j.yqres.2011.09.010

Marret, F., Zonneveld, K.A.F., 2003. Atlas of modern organic-walled dinoflagellate cyst distribution. Review of Palaeobotany and Palynology 125, 1-200.

Martrat, B., Grimalt, J.O., Shackleton, N.J., de Abreu, L., Hutterli, M.A., Stocker, T.F., 2007. Four Climate Cycles of Recurring Deep and Surface Water Destabilizations on the Iberian Margin. Science 317, 502-507. doi:10.1126/science.1139994

Mauritzen, C., Morel, Y., Paillet, J., 2001. On the influence of Mediterranean water on the central waters of the North Atlantic Ocean. Deep Sea Research Part I: Oceanographic Research Papers 48, 347-381.

Mertens, K.N., Takano, Y., Head, M.J., Matsuoka, K., 2014. Living fossils in the Indo-Pacific warm pool: A refuge for thermophilic dinoflagellates during glaciations. Geology 42, 531534. doi:10.1130/G35456.1

Mertens, K.N., Verhoeven, K., Verleye, T., Louwye, S., Amorim, A., Ribeiro, S., Deaf, A.S., Harding, I., De Schepper, S., Kodrans-Nsiah, M., de Vernal, A., Radi, T., Dybkjaer, K., Poulsen, N.E., Feist-burkhardt, S., Chitolie, J., González Arango, C., Heilmann-Clausen, C., Londeix, L., Turon, J.-L., Marret, F., Matthiessen, J., McCarthy, F.M.G., Prasad, V., Pospelova, V., Kyffin Hughes, J.E., Riding, J.B., Rochon, A., Sangiorgi, F., Welters, N., Sinclair, N., Thun, C., Soliman, A., Van Nieuwenhove, N., Vink, A., Young, M., 2009. Determining the absolute abundance of 
dinoflagellate cysts in recent marine sediments: the Lycopodium marker-grain method put to the test. Review of Palaeobotany and Palynology 157, 238-252.

Millennium Assessment Synthesis Reports, 2005. Chap 4. Ecosystems and Human Wellbeing: Biodiversity Synthesis. http://www.millenniumassessment.org/en/Synthesis.html

Moorthi, S.D., Countway, P.D., Stauffer, B.A., Caron, D.A., 2006. Use of Quantitative RealTime PCR to Investigate the Dynamics of the Red Tide Dinoflagellate Lingulodinium polyedrum. Microbial Ecology 52, 136-150. doi:10.1007/s00248-006-9030-3

Morzadec-Kerfourn, M.-T., 1977. Les kystes de dinoflagellés dans les sédiments récents le long des côtes Bretonnes. Rev. de Micropaléontologie 20, 157-166.

Morzadec-Kerfourn, M.-T., 1992. Estuarine Dinoflagellate cysts among oceanic assemblages of Pleistocene Deep-Sea sediments from the west African Margin and their paleoenvironmental significance, in: Head, M.J., Wrenn, J.H. (Eds.), Neogene and Quaternary Dinoflagellate Cyst of the North Atlantic Ocean and Adjacent Seas: Ecostratigraphy and Biostratigraphy. AASP Foundation, pp. 133-146.

Pailler, D., Bard, E.U. sciencedirect. com/science/article/B6V6.-45JYD3Y1/1/b82650723dcb3f66b8a4deb6c13ddda1, 2002. High frequency palaeoceanographic changes during the past $140000 \mathrm{yr}$ recorded by the organic matter in sediments of the Iberian Margin. Palaeogeography, Palaeoclimatology, Palaeoecology 181, 431-452.

Peliz, Á., Dubert, J., Santos, A.M.P., Oliveira, P.B., Le Cann, B., 2005. Winter upper ocean circulation in the Western Iberian Basin-Fronts, Eddies and Poleward Flows: an overview. Deep Sea Research Part I: Oceanographic Research Papers 52, 621-646. doi:10.1016/j.dsr.2004.11.005 
Penaud, A., Eynaud, F., Turon, J.L., Zaragosi, S., Marret, F., Bourillet, J.F., 2008. Interglacial variability (MIS 5 and MIS 7) and dinoflagellate cyst assemblages in the Bay of Biscay (North Atlantic). Marine Micropaleontology 68, 136-155.

Penaud, A., 2009. Interactions climatiques et hydrologiques du système Méditerranée/Atlantique au Quaternaire. Bordeaux 1.

Penaud, A., Eynaud, F., Turon, J.L., Blamart, D., Rossignol, L., Marret, F., Lopez-Martinez, C., Grimalt, J.O., Malaizé, B., Charlier, K., 2010. Contrasting paleoceanographic conditions off Morocco during Heinrich events (1 and 2) and the Last Glacial Maximum. Quaternary Science Reviews 29, 1923-1939.

Penaud, A., Eynaud, F., Sanchez Goni, M.F., Malaizé, B., Turon, J.L., Rossignol, L., 2011. Contrasting sea-surface responses between the western Mediterranean Sea and eastern subtropical latitudes of the North Atlantic during abrupt climatic events of MIS 3. Marine Micropaleontology 80, 1-17.

Penaud et al., in prep. A regional overview of the last glacial period in the temperate NE Atlantic: varying paleoproductivity centers over the last 50 ka BP.

Poirier, R.K., Billups, K., 2014. The intensification of northern component deepwater formation during the mid-Pleistocene climate transition: Mid-Pleistocene deep water circulation. Paleoceanography 29, 1046-1061. doi:10.1002/2014PA002661

Price, A.M., Pospelova, V., 2014. Spiniferites multisphaerus, a new dinoflagellate cyst from the Late Quaternary of the Guaymas Basin, Gulf of California, Mexico. Palynology 38, 101116. doi:10.1080/01916122.2013.864341 
Rattinacannou J.-E., 2007. Paléoclimat et paléocirculation hydrologique à Gibraltar lors de la transition MIS 12-11; enregistrement des dinokystes et comparaison avec les transitions vers l'Eémien et vers l'Holocène (Master 2 Envolh report, Univ. Bordeaux 1).

Richter, T.O., Van Der Gaast, S., Koster, B., Vaars, A., Gieles, R., de Stigter, H.C., de Haas, H., Van Weering, T.C.E., 2006. The Avaatech XRF Core Scanner: technical description and applications to NE Atlantic sediments., in: Rothwell, R.G. (Ed.), New Techniques in Sediment Core Analysis. Geological Society Special Publications, London, pp. 39-50.

Relvas, P., Barton, E.D., Dubert, J., Oliveira, P.B., Peliz, Á., da Silva, J.C.B., Santos, A.M.P., 2007. Physical oceanography of the western Iberia ecosystem: Latest views and challenges. Progress in Oceanography 74, 149-173. doi:10.1016/j.pocean.2007.04.021

Rochon, A., de Vernal, A., Turon, J.-L., Matthiessen, J., Head, M.J. (Eds.), 1999. Distribution of dinoflagellate cysts in surface sediments from the North Atlantic Ocean and adjacent basins and quantitative reconstruction of sea-surface parameters. AASP special pub.

Rogerson, M., Colmenero-Hidalgo, E., Levine, R.C., Rohling, E.J., Voelker, A.H.L., Bigg, G.R., Schönfeld, J., Cacho, I., Sierro, F.J., LÃwemark, L., Reguera, M.I., De Abreu, L., Garrick, K., 2010. Enhanced Mediterranean-Atlantic exchange during Atlantic freshening phases. Geochemistry, Geophysics, Geosystems 11.

Rohling, E.J., Medina-Elizalde, M., Shepherd, J.G., Siddall, M., Stanford, J.D., 2012. Sea surface and high-latitude temperature sensitivity to radiative forcing of climate over several glacial cycles. Journal of Climate 25, 1635-1656. 
Rohling, E.J., Pujol, C., Den Dulk, M., Vergnaud-Grazzini, C., 1995. Abrupt hydrographic change in the Alboran Sea (western Mediterranean) around 8000 yrs BP. Deep Sea Research Part I: Oceanographic Research Papers 42, 1609-1619.

Rouis-Zargouni, I., Turon, J.-L., Londeix, L., Kallel, N., Essallami, L., 2012. The last glacialinterglacial transition and dinoflagellate cysts in the western Mediterranean Sea. Comptes Rendus Geoscience 344, 99-109. doi:10.1016/j.crte.2012.01.002

Sætre, M.M.L., Dale, B., Abdullah, M.I., Sætre, G.-P., 1997. Dinoflagellate Cysts as Potential Indicators of Industrial Pollution in a Norwegian Fjord. Marine environmental Research 44, 167-189.

Sànchez-Goñi, M.F., Eynaud, F., Turon, J.L., Shackleton, N.J., 1999. High resolution palynological record off the Iberian margin: direct land-sea correlation for the Last Interglacial complex. Earth and Planetary Science Letters 171, 123-137.

Sànchez-Goñi, M.F., Turon, J.-L., Eynaud, F., Gendreau, S., 2000. European Climatic Response to Millennial-Scale Changes in the Atmosphere-Ocean System during the Last Glacial Period. Quaternary Research 54, 394-403.

Sànchez-Goñi, M.F., 2006. Interactions végétation-climat au cours des derniers 425.000 ans en Europe occidentale. Le message du pollen des archives marines. Quaternaire. Revue de I'Association française pour l'étude du Quaternaire 17, 3-25.

Sànchez-Goñi, M.F., Landais, A., Fletcher, W.J., Naughton, F., Desprat, S., Duprat, J., 2008. Contrasting impacts of Dansgaard-Oeschger events over a western European latitudinal transect modulated by orbital parameters. Quaternary Science Reviews $27,1136-1151$. 
Sànchez-Goñi, M.F., Llave E., Oliveira D., Naughton F., Desprat S., Ducassou E., Hodell D.A. (this volume). Climate changes in south western Iberia and Mediterranean Outflow variations during two contrasting cycles of the last 1 Myrs: MIS 31-MIS 30 and MIS 12- MIS 11, Global and Planetary Change, submitted

Shackleton, N.J., Chapman, M., Sanchez-Goni, M.F., Pailler, D., Lancelot, Y., 2000. The Classic Marine Isotope Substage 5e. Quaternary Research 58, 14-16.

Shackleton, N.J., Sanchez-Goni, M.F., Pailler, D., Lancelot, Y., 2003. Marine Isotope Substage 5e and the Eemian Interglacial. Global and Planetary Change 36, 151-155.

Shin, H.H., Mizushima, K., Oh, S.J., Park, J.S., Noh, I.H., Iwataki, M., Matsuoka, K., Yoon, Y.H., 2010. Reconstruction of historical nutrient levels in Korean and Japanese coastal areas based on dinoflagellate cyst assemblages. Marine Pollution Bulletin 60, 1243-1258. doi:10.1016/j.marpolbul.2010.03.019

Siddall, M., Rohling, E.J., Almogi-Labin, A., Hemleben, C., Meischner, D., Schmelzer, I., Smeed, D.A., 2003. Sea-level fluctuations during the last glacial cycle. Nature 423, 853-858. doi:10.1038/nature01690

Sprangers, M., Dammers, N., Brinkhuis, H., van Weering, T.C.., Lotter, A.F., 2004. Modern organic-walled dinoflagellate cyst distribution offshore NW Iberia; tracing the upwelling system. Review of Palaeobotany and Palynology 128, 97-106. doi:10.1016/S00346667(03)00114-3

Stockmarr, J., 1971. Tablets with spores used in absolute pollen analysis. Pollen et Spores XIII (4), 615-621. 
Targarona, J., Warnaar, J., Boessenkool, K.P., Brinkhuis, H., Canals, M., 1999. Recent Dinoflagellate cyst distribution in the North Canary Basin, NW Africa. Grana 38, 170-178. doi:10.1080/00173139908559225

Thomas, W.H., Gibson, C.H., 1990. Quantified small-scale turbulence inhibits a red tide dinoflagellate Gonyaulax polyedra Stein. Deep Sea Res. 37, 1583-1593.

Thomas, W.H., Gibson, C.H., 1992. Effects of quantified small-scale turbulence on the dinoflagellate, Gymnodinium sanguineum (splendens): contrasts with Gonyaulax (Lingulodinium) polyedra, and the fishery implication. Deep-sea Research 39, 1429-1437.

Turon, J.-L., 1978. Les dinoflagellés témoins des paléoenvironnements durant l'Holocène dans I'Atlantique Nord Oriental. Signification paléohydrologique et paléoclimatique. C.R. Acad. Sc. Paris 286, 1861-1864.

Turon, J.-L., 1984. Le palynoplancton dans l'environnement actuel de I'Atlantique Nordoriental. Evolution climatique et hydrologique depuis le dernier maximum glaciaire. Mémoires de l'Institut de Géologie du Bassin d'Aquitaine 17, 313 pp.

Turon, J.-L., Lezine, A.-M., Denefle, M., 2003. Land-sea correlations for the last glaciation inferred from a pollen and dinocyst record from the portuguese margin. Quaternary Research 59, 88-96.

Turon, J.-L., Londeix, L., 1988. Les asssemblages de kystes de dinoflagellés en Méditerranée occidentale (Mer d'Alboran): mise en evidence de l'évolution des paléoenvironnement depuis le dernier maximum glaciaire. Bull. Centres Rech. Explor.-prod. Elf-Aquitaine 12, 313344. 
Voelker, A.H.L., de Abreu, L., 2011. A Review of Abrupt Climate Change Events in the Northeastern Atlantic Ocean (Iberian Margin): Latitudinal, Longitudinal, and Vertical Gradients, in: Rashid, H., Polyak, L., Mosley-Thompson, E. (Eds.), Geophysical Monograph Series. American Geophysical Union, Washington, D. C., pp. 15-37.

Voelker, A.H.L., Lebreiro, S.M., SchÃ Infeld, J., Cacho, I., Erlenkeuser, H., Abrantes, F., 2006. Mediterranean outflow strengthening during northern hemisphere coolings: A salt source for the glacial Atlantic? Earth and Planetary Science Letters 245, 39-55.

Wall, D., and B. Dale, 1966. Living fossils in western Atlantic plankton, Nature, 211, 10251027, doi:10.1038/2111025a0.

Weaver, A.J., 2004. The UVic Earth System Climate Model and the thermohaline circulation in past, present and future climates. The State of the Planet: Frontiers and Challenges in Geophysics 279-296.

Williams, D. B., 1971. The distribution of marine dinoflagellates in relation to physical and chemical conditions. B.M. Funnel and W.R. Riedel (Editors), Cambridge University Press, pp. 91-95.

Willis, K.J., Bailey, R.M., Bhagwat, S.A., Birks, H.J.B., 2010. Biodiversity baselines, thresholds and resilience: testing predictions and assumptions using palaeoecological data. Trends in Ecology \& Evolution 25, 583-591. doi:10.1016/j.tree.2010.07.006

Zaragosi, S., Eynaud, F., Pujol, C., Auffret, G.A., Turon, J.L., Garlan, T., 2001. Initiation of the European deglaciation as recorded in the northwestern Bay of Biscay slope environments (Meriadzek Terrace and Trevelyan Escarpment): A multi-proxy approach. Earth and Planetary Science Letters 188, 493-507. 
Zippi, P.A., 1992. Dinoflagellate cyst stratigraphy and climate fluctuations in the eastern North Atlantic during the last 150,000 years. In: Neogene and Quaternary Dinoflagellate Cyst of the North Atlantic Ocean and Adjacent Seas: Ecostratigraphy and Biostratigraphy,. Head, M.J., Wrenn, J.H. (Eds.)., pp. 55-68.

Zonneveld, K.A.F., 1997. Dinoflagellate cyst distribution in surface sediments from the Arabian Sea (northwestern Indian Ocean) in relation to temperature and salinity gradients in the upper water column. Deep Sea Research Part II: Topical Studies in Oceanography 44, $1411-1443$.

Zonneveld, K.A.F., Brummer, G.A., 2000. (Palaeo-)ecological significance, transport and preservation of organic-walled dinoflagellate cysts in the Somali Basin, NW Arabian Sea. Deep Sea Research Part II: Topical Studies in Oceanography 47, 2229-2256.

Zonneveld, K.A.F., Chen, L., Elshanawany, R., Fischer, H.W., Hoins, M., Ibrahim, M.I., Pittauerova, D., Versteegh, G.J.M., 2012. The use of dinoflagellate cysts to separate humaninduced from natural variability in the trophic state of the Po River discharge plume over the last two centuries. Marine Pollution Bulletin 64, 114-132. doi:10.1016/j.marpolbul.2011.10.012

Zonneveld, K.A.F., Marret, F., Versteegh, G.J.M., Bogus, K., Bonnet, S., Bouimetarhan, I., Crouch, E., de Vernal, A., Elshanawany, R., Edwards, L., Esper, O., Forke, S., Grøsfjeld, K., Henry, M., Holzwarth, U., Kielt, J.F., Kim, S.Y., Ladouceur, S., Ledu, D., Chen, L., Limoges, A., Londeix, L., Lu, S.H., Mahmoud, M.S., Marino, G., Matsouka, K., Matthiessen, J., Mildenhal, D.C., Mudie, P., Neil, H.L., Pospelova, V., Qi, Y., Radi, T., Richerol, T., Rochon, A., Sangiorgi, F., Solignac, S., Turon, J.L., Verleye, T., Wang, Y., Wang, Z., Young, M., 2013. Atlas of modern dinoflagellate cyst distribution based on 2405 datapoints. Review of Palaeobotany and 


\section{Table caption}

Table 1: key information regarding the set of cores used for this study.

\begin{tabular}{|c|ccc|c|l|}
\hline Core & Latitude & Longitude & $\begin{array}{c}\text { Water } \\
\text { depth }(\mathrm{m})\end{array}$ & $\begin{array}{c}\text { Marine } \\
\text { isotopic } \\
\text { stage }\end{array}$ & References, Datasources \\
\hline $\begin{array}{c}\text { IODP339 1385 } \\
\text { D10H }\end{array}$ & $\mathbf{3 7 . 8}$ & $\mathbf{- 1 0 . 0 2}$ & $\mathbf{3 1 4 6}$ & $\mathbf{1 1 , 1 9}$ & This work, Oliviera, Sanchez-Goni, in prep. \\
SU81-18 & 37.77 & -10.18 & 3155 & 1 & Le Coeur, L., unpublished; Turon et al., 2003 \\
ODP976 & 36.20 & -4.30 & 1108 & $\mathbf{1 , 5 , 1 1 ,}$ & $\begin{array}{l}\text { Combourieu Nebout et al., 1999; 2002; Levi C., } \\
\text { unpublished; Rattinacannou J.-E., unpublished }\end{array}$ \\
MD95-2042 & 37.80 & -10.17 & 3146 & 3,5 & Eynaud, 1999; Eynaud et al., 2000 \\
MD95-2043 & 36.14 & -2.62 & 1841 & 1,3 & Rouis-Zargouni, 2010, Penaud, 2009 \\
MD99-2339 & 35.89 & -7.53 & 1177 & 1 & Penaud, 2009, Penaud et al., 2011 \\
MD04-2805CQ & 34.52 & -7.02 & 859 & 1 & Penaud et al., 2010 \\
\hline
\end{tabular}

Table 1 


\section{Figure / plate caption}

Figure 1: (a) location of the cores of interest (IODP 339 U1385, SU81-18, MD95-2042, MD992339, MD04-2805CQ) with a sketch of the modern sea-surface hydrological dynamics (main currents, $P C=$ Portugal current, $C C=$ Canary current, NAD = North Atlantic drift); (b) detailed view of the modern surface dynamic structures, with: IPC: Iberian Poleward Current, AC: Azores Current, WIWF: Western Iberia Winter Front, after Peliz et al. (2005); and WAG: Western Alboran Gyre, EAG: Eastern Alboran Gyre, AOF: Almería-Oran Front after Hauschildt et al. (1999).

Green empty circle: "SHACK area" identifying the location of twin and/or proximal cores (i.e. SU81-18/ MD95-2042) of the "Shackleton site" - IODP 339 U1385.

Figure 2: Main dinocyst taxa shifts (relative abundances) over the "SHACK area" for the last one million years as depicted by a composite sequence consisting of interglacials from cores SU81-18 (e.g. Turon et al. 2003), MD95-2042 (e.g. Eynaud 1999; Eynaud et al. 2000) and IODP 339 U1385 (this work). Full interglacial conditions are highlighted by pink bands for LR04 Benthic $\delta^{18}$ O stack (Lisiecki and Raymo, 2005) values under $4 \%$ \%.

Figure 3: (a) Comparison of interglacial signals along time and space of some selected dinocyst groups and species plotted versus isotopic $\delta^{18} \mathrm{O}$ data of the respective cores, the LR04 Benthic $\delta^{18} \mathrm{O}$ stack (Lisiecki and Raymo, 2005) and the $65^{\circ} \mathrm{N}$ summer insolation data (Berger and Loutre, 1991; pink band locate insolation values $\geq 450 \mathrm{~W} . \mathrm{m}^{-2}$ ). Mid-Brunhes Event (MBE) after Candy et al., 2010.

$\%$ L.mac. $=$ relative abundances, i.e. percentages of Lingulodinium machaerophorum; $\Sigma$ heterotr. dino. $=$ sum of the relative abundances of heterotrophic dinocysts (taxa list after Marret and Zonneveld, 2003); $\Sigma$ W. Impagidinium = sum of the relative abundances of the 
warm Impagidinium : I. patulum, I. paradoxum, I. aculeatum and I. sphaericum). Yelow bands locate the $\Sigma$ W. Impagidinium maxima on the "SHACK area".

(b) synchronisation of the $\Sigma$ W. Impagidinium signals from cores SU81-18 (e.g. Turon et al. 2003) , MD95-2042 (e.g. Eynaud 1999; Sànchez-Goñi et al., 1999; Eynaud et al. 2000; Sànchez-Goñi et al., 2008) and IODP 339 U1385 (this work) over Terminations 1, 2 and 9 in concordance with the LRO4 Benthic $\delta^{18} \mathrm{O}$ stack (Lisiecki and Raymo, 2005). Note the good coherency of dinocyst derived data (suborbital events included) along comparable sections.

Figure 4: Sea-surface key proxies (from dinocysts, foraminifera and alkenones) compared to continental ones (Mediterranean forest) over a composite sequence gathering data from cores SU81-18 (e.g. Le Coeur, 1993, Turon et al., 2003), MD95-2042 (e.g. Sanchez-Goñi et al., 1999; Eynaud et al., 2000; Sanchez-Goñi et al., 2008) and IODP 3391385 (this work, SanchezGoni et al., in progress, Oliviera et al., in progress). Derived SST from alkenone data: for MIS 1 and 5 from core MD95-2042 after Pailler and Bard (2002), for core MD01-2443 after Martrat et al. (2007). Percentages of the polar taxa Neogloboquadrina pachyderma sinistral (Nps) after Turon et al; (2003) for core SU81-18, after Sanchez-Goni et al., (2006) for core MD95-2042 and after Voelker and de Abreu (2011) for core MD01-2443. Marine isotopic stage limits after Lisiecki \& Raymo (2005). Note the progressive regression of the S. ramosus through time.

Figure 5: Compilation of some archives of interest along the last 810 ka with: (a) Eccentricity cycles (after Berger \& Loutre, 1991),(b) LR04 Benthic $\delta^{18}$ O stack (Lisiecki and Raymo, 2005), (c) $\mathrm{CO}_{2}$ data (ppmv) compiled from Antarctic Ice Cores (from http://ncdc.noaa.gov/paleo/study/17975), (d) IODP339 U1385 XRF data Log (Ca/Ti) after Hoddel et al. (2013), (e) Dust content in the marine core MD03-2705 (terrigeneous content 100\% - CaCO3) after Malaizé et al. (2012), (f) Mean Grain Size (normalized) after Clemens et al. (2008), (g) periods of strong Aguhlas linkage (adapted from Caley et al., 2012). These sequences are compared to $(h)$ the dinocyst $W /(W+C)$ ratio from the Alboran ODP976 site and from the "SHACK" area (SU81-18 / MD95-2042 and IODP 339 U1385), together with the 
PCA analysis results of this composite dinocyst record (see methods) as seen throughout the first 3 components (from F1 (i) to F3 (k), representing $30 \%$ of the total variance).

Plate 1: Some common specimens from IODP 3391385 (HoleD). Scale bar = $50 \mu \mathrm{m}$. (a) Impagidinium patulum; (b, h) Selenopemphix nephroides; (c) Spiniferites membranaceus; (d) Stelladinium stellatum; (e) Spiniferites lazus; (f) Brigantedinium carioense; (g) Impagidinium aculeatum. 
Figure 1
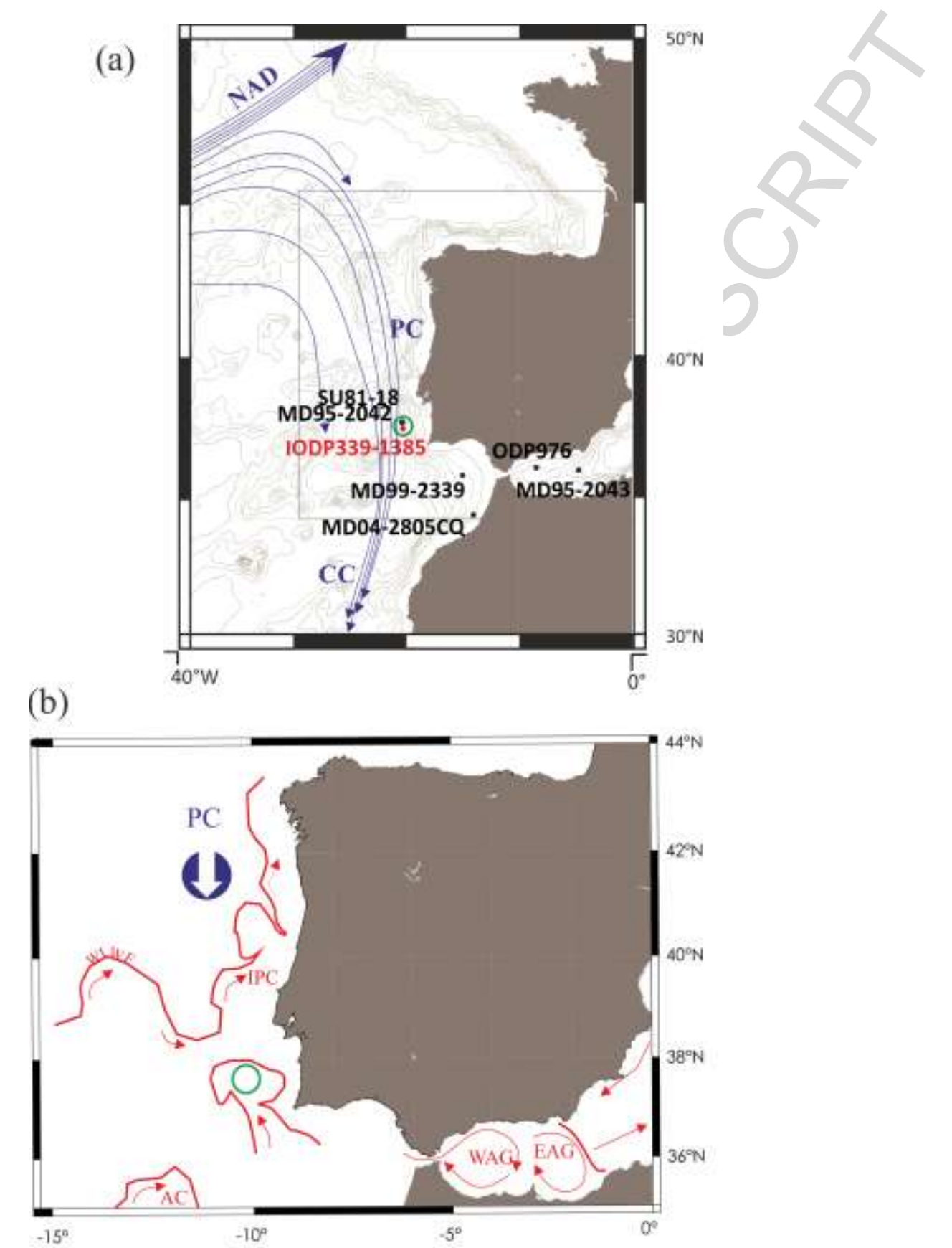
Figure 2
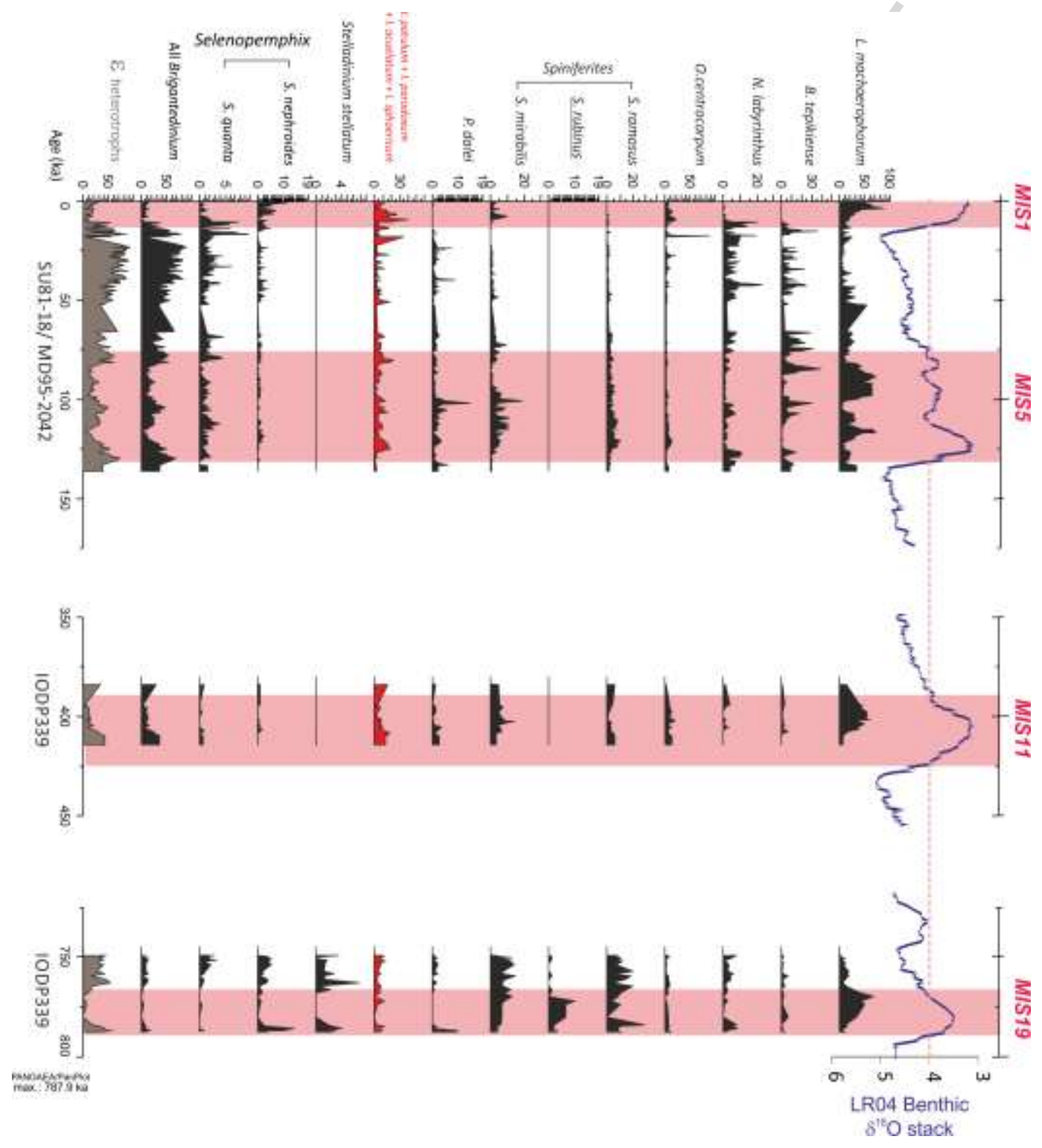


\section{Figure 3}

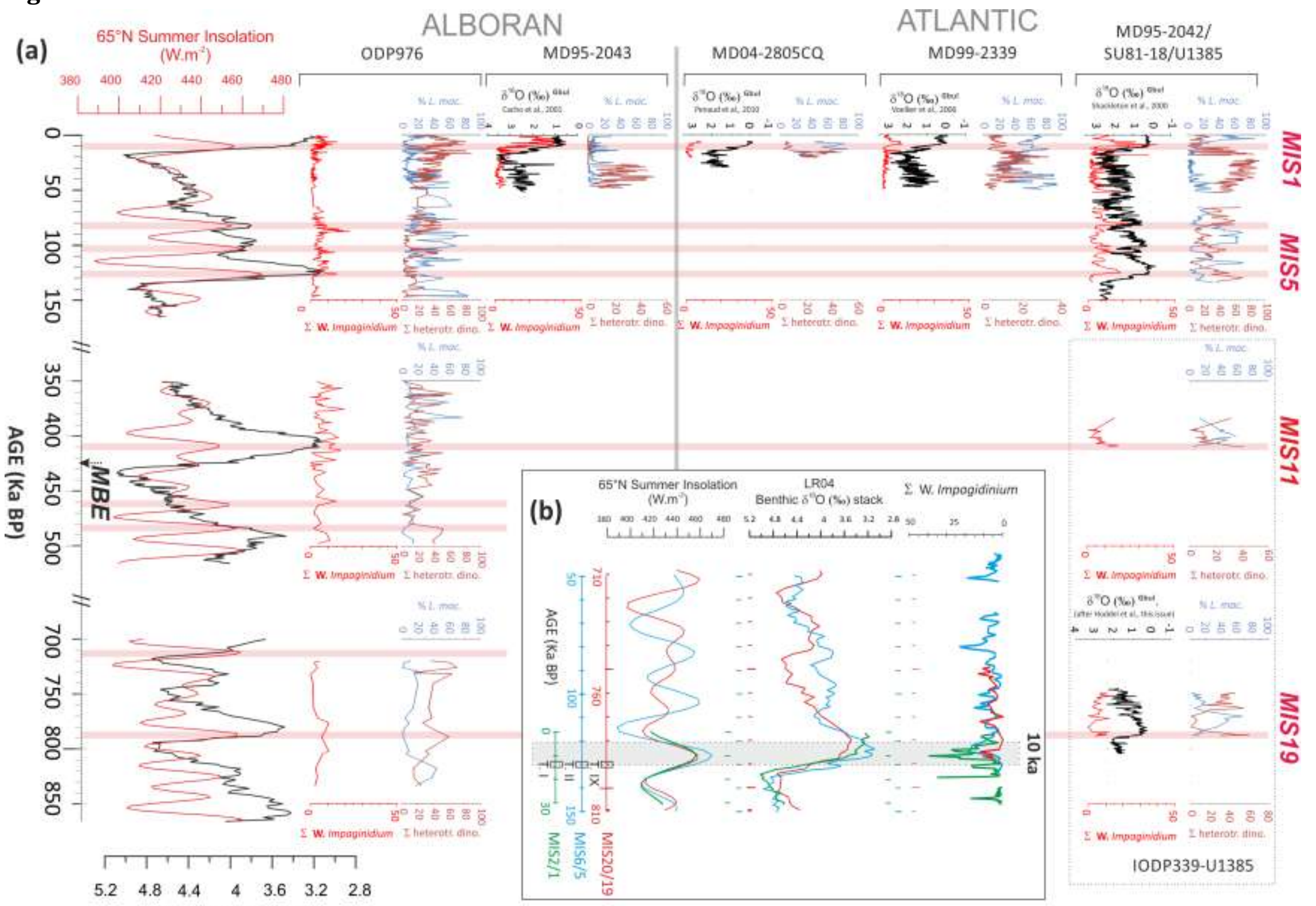




\section{Figure 4}
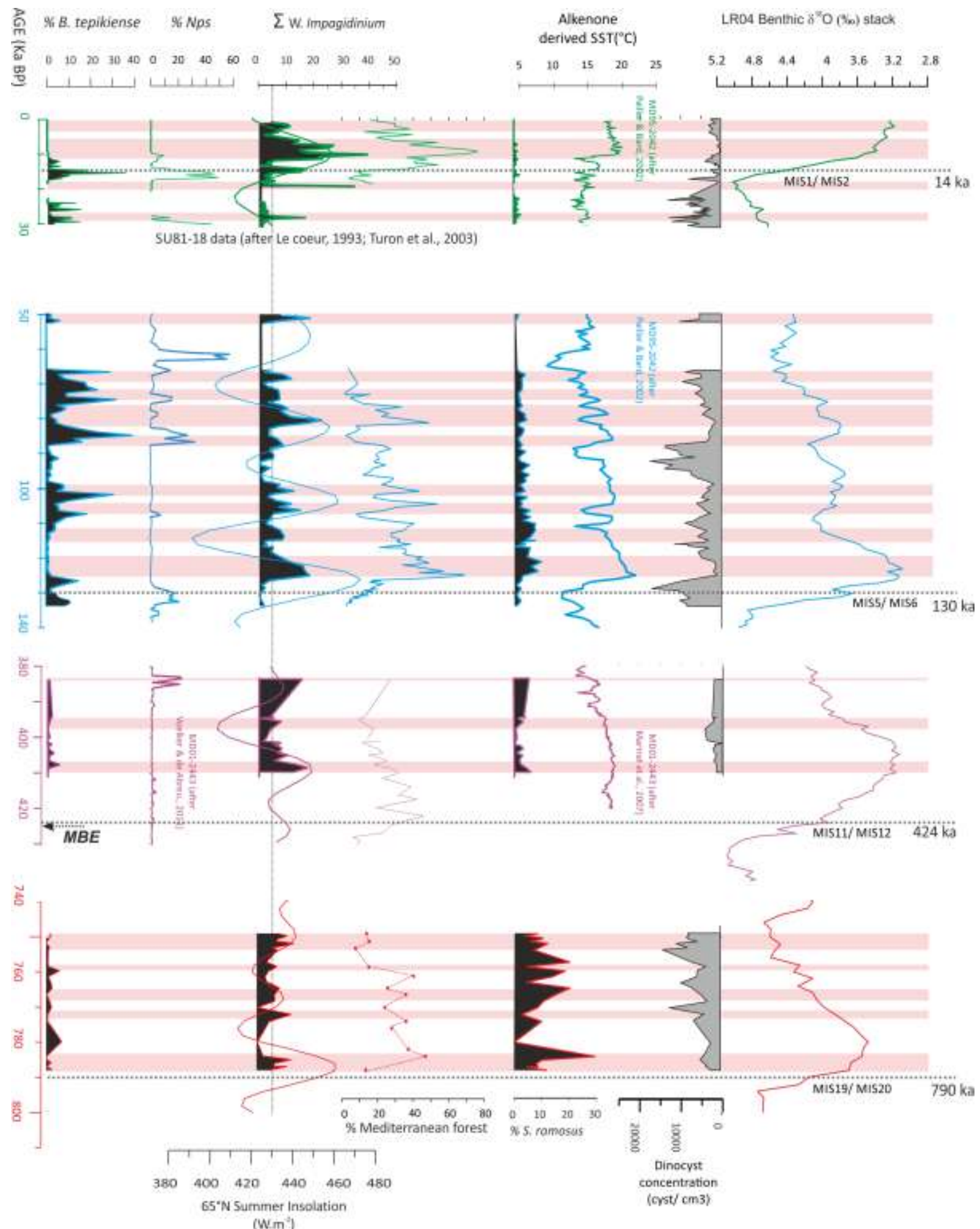
Figure 5

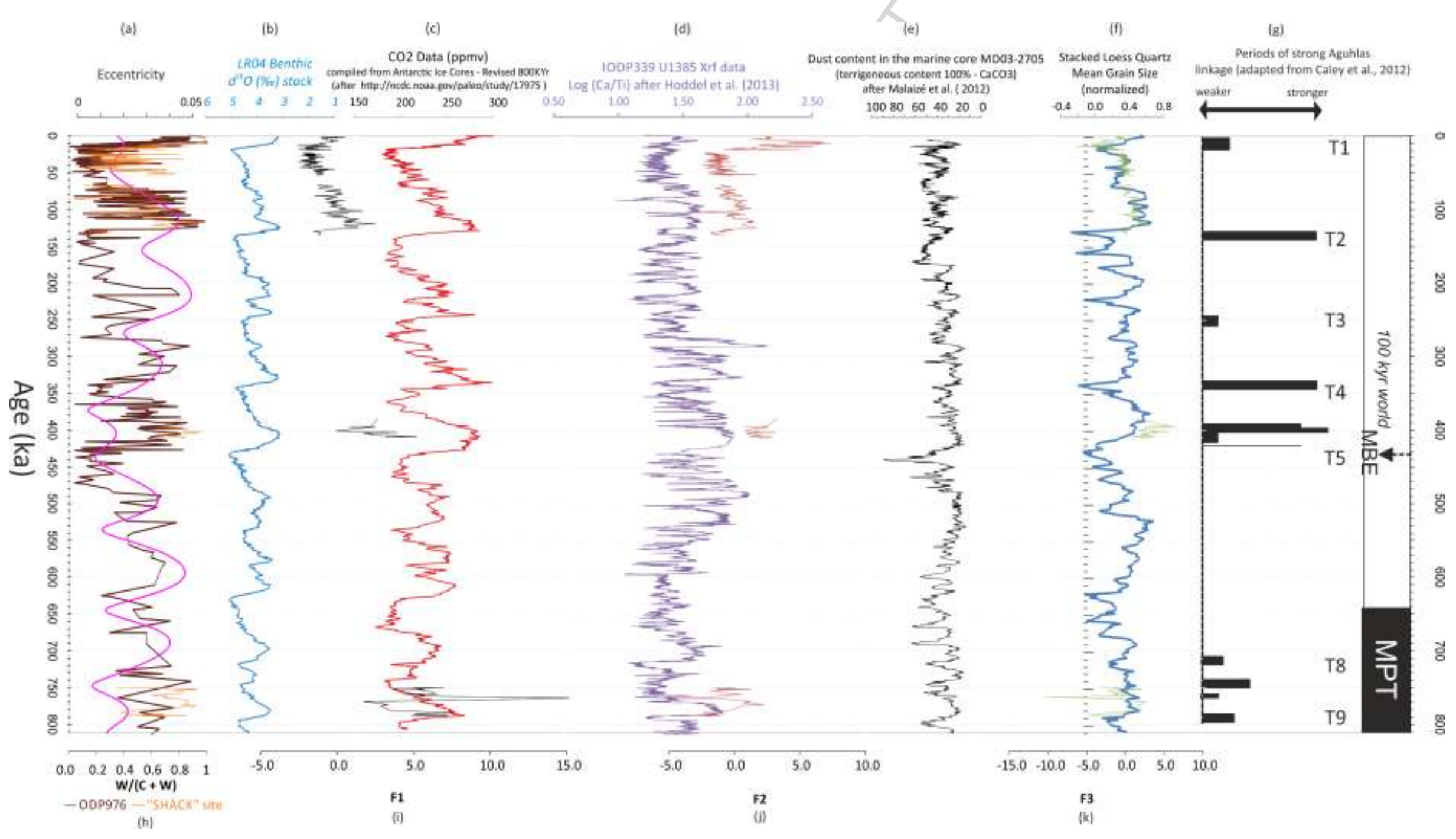




\section{ACCEPTED MANUSCRIPT}
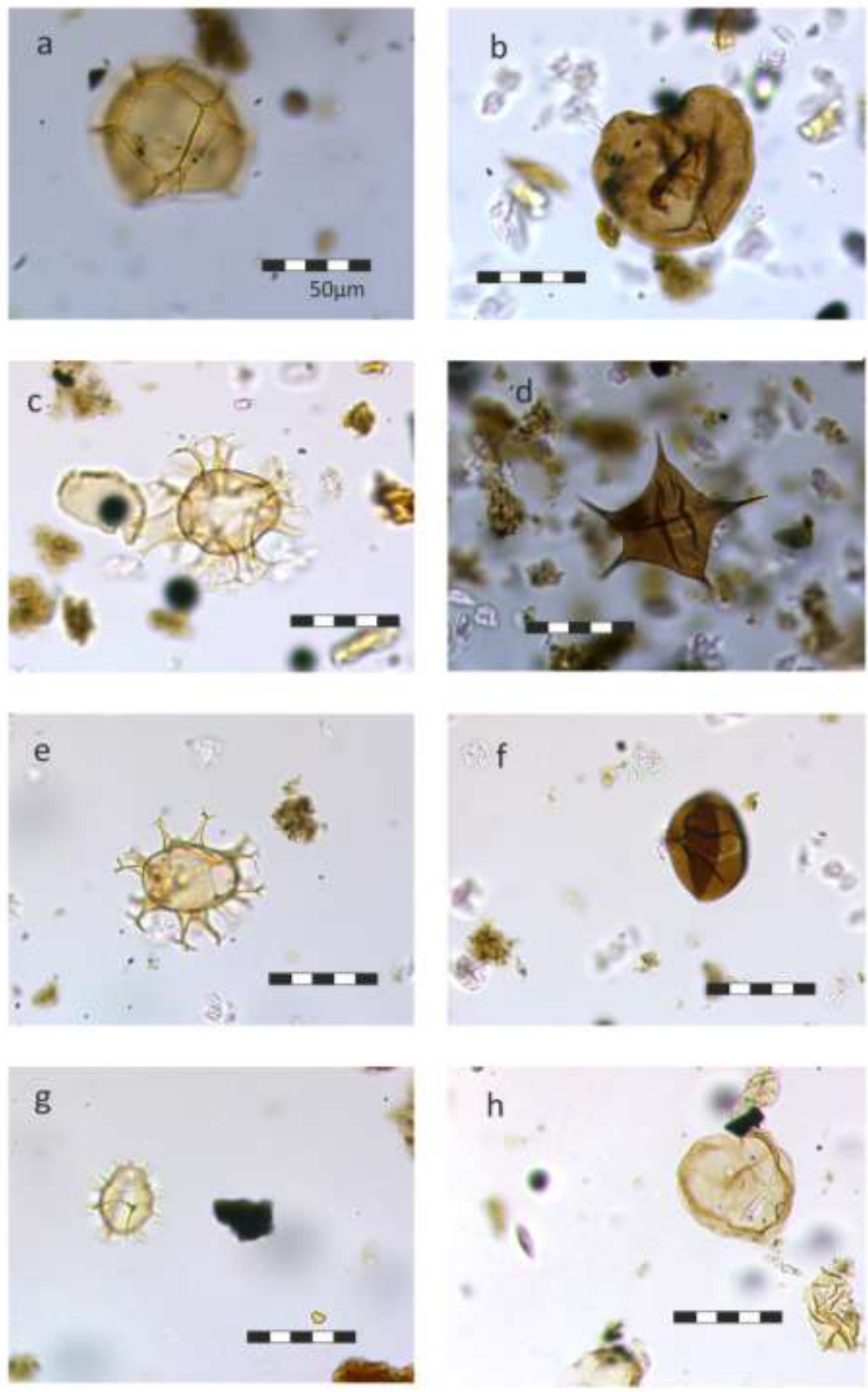

\section{Plate 1}




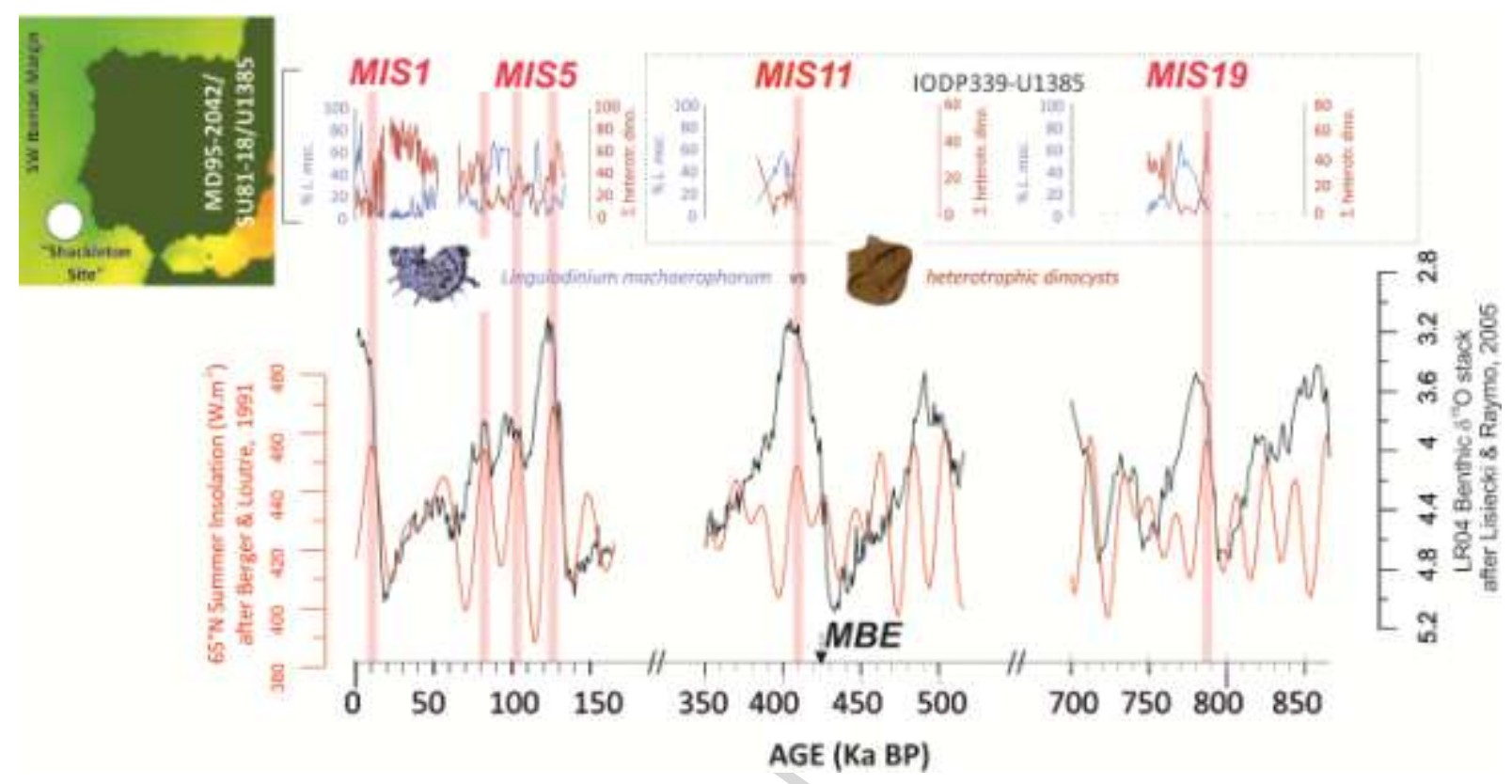

Graphical abstract 


\section{Highlights}

Southern Iberian margin dinocysts are studied from long sedimentary records (including IODP site U1385)

Evolution of dinocyst populations is analyzed over the last 800 ka focusing on past interglacials

Coherent and reproducible patterns are detected within dominant cyst species on long term trends

Mediterranean /Atlantic exchanges are illustrated based on the comparison of inter-basin populations 